\title{
Silos e sua construção
}

\author{
AULA INAUGURAL DE 1948 \\ dada pelo Professor Eng. ${ }^{\circ}$ \\ ORLANDO CARNEIRO
}

\section{INDICE}

Definição e finalidades .... 4

Classificação geral ....... 4

Vantagens e inconvenientes . 5

Capacidade ........... 6

Condições de estabilidade .. 7

Requisitos importantes ..... 14

Partes essenciais do silo ... 15
Descrição dos diferentes tipos projetados ............ 19

Carga ............... 31

Descarga $\ldots \ldots \ldots \ldots \ldots \ldots \ldots 31$

Silos grandes ou pequenos? . 33

Localização ............ 33 


\section{DEFINIÇAO E FINALIDADES}

Os silos são construçōes destinadas ao armazenamento e conservação de grãos secos, sementes, cereais e forragens verdes.

Como a primeira cousa a resolver é a escolha do tipo a ser construido, indicamos, logo abaixo, um quadro de classificaçăo geral dos sillos.

Essa escolha depende, naturalmente, dos recursos e importancia da propriedade agrícola e da maior ou menor facilidade de obtenção dos materiałs para a sua construção.

\section{CLASSIFICAÇAOO GERAL}

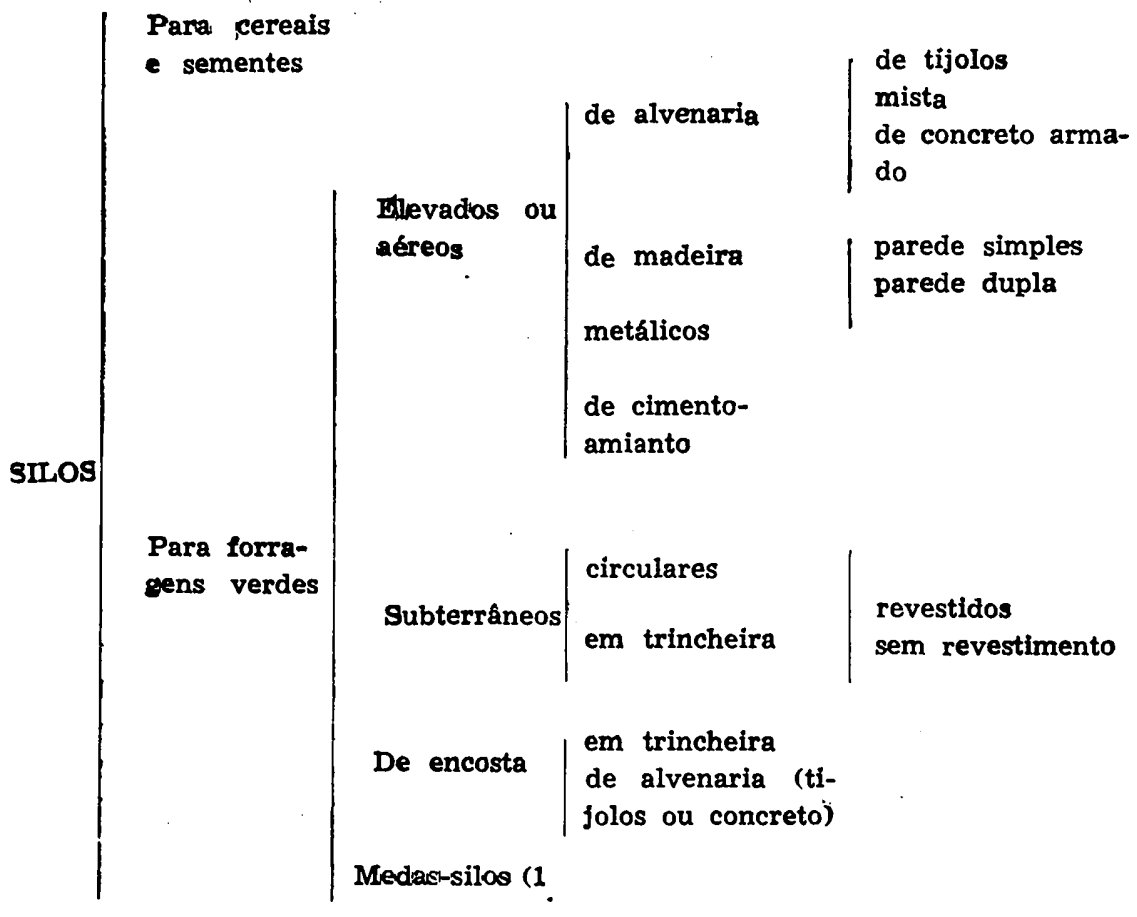

(1) As medas de capim foram incluidas nesta classificaçâo gental, mas nâo merecem a denominaçâo de silo. 
Os silas destinados exclusivamente para cereais e sementes săo construçóes de vulto, em geral exigindo cálculos de resistencia e cuidados especiais com a sua estrutura. Podem ser elevados ou subterraneas.

Vamos nos ocupar, principalmente, dos silos destinados a forragens verdes.

$\mathbf{E}^{\prime}$ verdade que estes, convenientemente reforçadas, podem servir também para aquele fim.

Formas - Os silas elevados, quando destinados a forragem verde, teem a forma de torre cllindrica: ou poligonal. Quando sáo empregados para armazenar gráas ou sementes, teem formas variadas. Os silos subterraneas podem ser de secçăo circular ou de secção trapezoldal, quando em trincheira.

\section{VANTAGENS E INCONVENIENTES}

Os sllos elevados são mals caros que os subterraneos, mas apresentam sôbre estes algumas vantagens: duração indeflnida, principalmente quando de alvenaria; mais secos; descarga mais fácil. Quando de madeira ou metálicas a conservaçăo é mais dispendiasa, pois necessitam de pinturas frequentes. A carga dos silos elevados é mais trabalhosa, porém a conservaçăo da forragem melhor.

Os silos subterraneos săo construçбes simples e economicas e se forem revestidos e bem impermeabilizados, podem durar muito, com bons resultados. A carga é mais comoda, mas a descarga mais trabalhosa. Devem ser bem protegidos contra as águas de chuva, de preferência por melo de telhados,

Nestes silos perde-se quase semple uma parte da forragem, devido a infiltraçōes da umidade, quando năo são bem impermeabilizados e náo cobertos.

Das silos elevados os de madeira são os mais baratos, mas náo săo os mais duráveis, além de serem sujeitos a incêndio, ataque de ratos e de dificll impermeabllizaçăo, quando de parede simples.

Os melhores, incontestavelmente, sob todos os pontos de vista, săo os silos elevados de alvenaria mista, tijolo reforçado com nervuras e cintas de concreto armado. São perfeitos, de custo relativamente baixo, resistentes e durávels.

Uma vez escolhido o tipo a construír, passaremos ao cálculo da capacidade. 
Anais dà E. S. A. "Luiz de Queiroz"

\section{CAPACIDADE}

Para sabermos quais as dimensóes que devemos dar ao śilo, de acôrdo com o número de cabeças e período em que as animais devem ser alimentados com a forragem ensilada, vamas admitir um consumo diario de 8 a $10 \mathrm{~kg}$ de forragem ensilada, em média, por cabeça de vaca leiteira, inclusive as perdas.

Para um perfodo de 150 dias, teríamos 1200 a $1500 \mathrm{~kg}$ de forragem.

Sendo de 600 a $700 \mathrm{~kg}$ o pesso de um metro cúbico de forragem, depois de ensilada e adensada, temos:

$$
\mathrm{v}=\frac{1200 \text { a } 1500}{600 \text { a } 700} \approx 2 \mathrm{~m}^{3} \text {, para } 150 \text { dias. }
$$

Para justificar a maneíra de expor os resultados aproximadamente, basta lembrarmos que as forragens verdes conforme o seu acondicionamento ou adensamento, podem ter a sua densidade variando de 0,2 a mais de 1 .

o importante é sabermos qual a aproximaçăo que se deve aceitar para cada caso.

Vemos, portanto, que o volume do silo é proporcional ao número de cabeças e ao período de utilizaçáo da forragem ensilada.

Se for silo subterraneo circular, ou elevado cilindrico, temos :

$V=\pi r 2 h$, sendo $\mathbf{r}$ o raio interno e $h$ a altura util.

Se for subterráneo em trincheira: $V=I_{m} h c$, sendo 1 a largura média; h a altura e c o comprimento. zoidal.

A seç̧⿸丆o de um silo em trincheira é, comumente, trape-

No primeiro caso, escolhida uma das duas dimensరes, a outra se deduz. Em geral a altura de um silo cilíndrico elevado é de 2,5 a 3 vezes o seu dímetro. Nas subterrâneas circulares, a profundidade não deve ir além de $6,00 \mathrm{~m}$, variando de 3 a $5 \mathrm{~m}$ o seu diametro.

Para os silos em trincheira; a largura média é de 2 a $3 \mathrm{~m}$ e a altura vaí até $3,00 \mathrm{~m}$.

Adotadas estas medidas, para êstes tipas de silo, só nas resta calcular o seu comprimento c uma vez conhecido o volume $\mathbf{v}$.

Exemplo : Para 60 cabeças, durante 150 dias, teríamas $\mathrm{V}=120 \mathrm{~m}^{3}$, de acordo com o que vimas atrás. Tratando-se de 
silo cilindrico, vem : $V=120 \mathrm{~m}^{3}=\pi \mathrm{r}^{2} \mathrm{~h}$; adotando-se $\mathrm{r}=2,00 \mathrm{~m}$, temos $\mathrm{h}=\frac{\mathrm{V}}{\pi \mathrm{r}^{2}}=\frac{120}{\pi \times 4,00}=\frac{120}{12,56} \approx 10 \mathrm{~m}$. Se o silo for em 1rincheira : $V=120 \mathrm{~m} 3=l_{\mathrm{m}} \times \mathrm{h} \times \mathrm{c}=2,50 \times 3,00 \times \mathrm{c}, \log 0$

$$
c=\frac{v}{l_{m} \times h}=\frac{120}{2,50 \times 3,00}=\frac{120}{7,50}=16 \mathrm{~m}
$$

\section{CONDIÇÕES DE ESTABILIDADE}

Silos elevados

Em relação às outras construções, o que um silo elevado, cilindrico, oferece de particular, quanto à estabilidade, são: pressão interna lateral, devida ao pêso do material com que se carrega o silo, e a ação do vento.

Pressão interna lateral : Vejamos como calcular êsses esforços, como dispor os reforços respectivos convenientemente. e quais devem ser as dimensões dêstes.

Tenho a pretenção de indicar, aquí, um meio simples e fácil de reter de memória e de calcular essa pressão, que tende abrir o silo segundo um plano vertical passando pelo centro (plano diametral).

Suponhamos, por um momento, que o silo é cheio com um líquido qualquer, água, por exemplo, passando a funcionar como reservatório.

Ora, a hidrostática nos ensina como obter o valor da fôrça que tende abrir o reservatório cilíndrico, (no nosso caso o silo) segundo êsse plano diametral.

Como a zona perigosa é no fundo, consideremos um elemento dS da superficie lateral, na parte mais baixa, de $1 \mathrm{~cm}$ de altura e largura variavel. Desenho n.1.

A pressão p sôbre êsse elemento é normal à superfície e tem para valor o pêso de uma coluna líquida, cujo volume tem para base o elemento $\mathbf{d S}$, no ponto $\mathbf{M}$ e para altura a distância do centro de gravidade do elemento de secção considerado, até a superfície livre do líquido. 


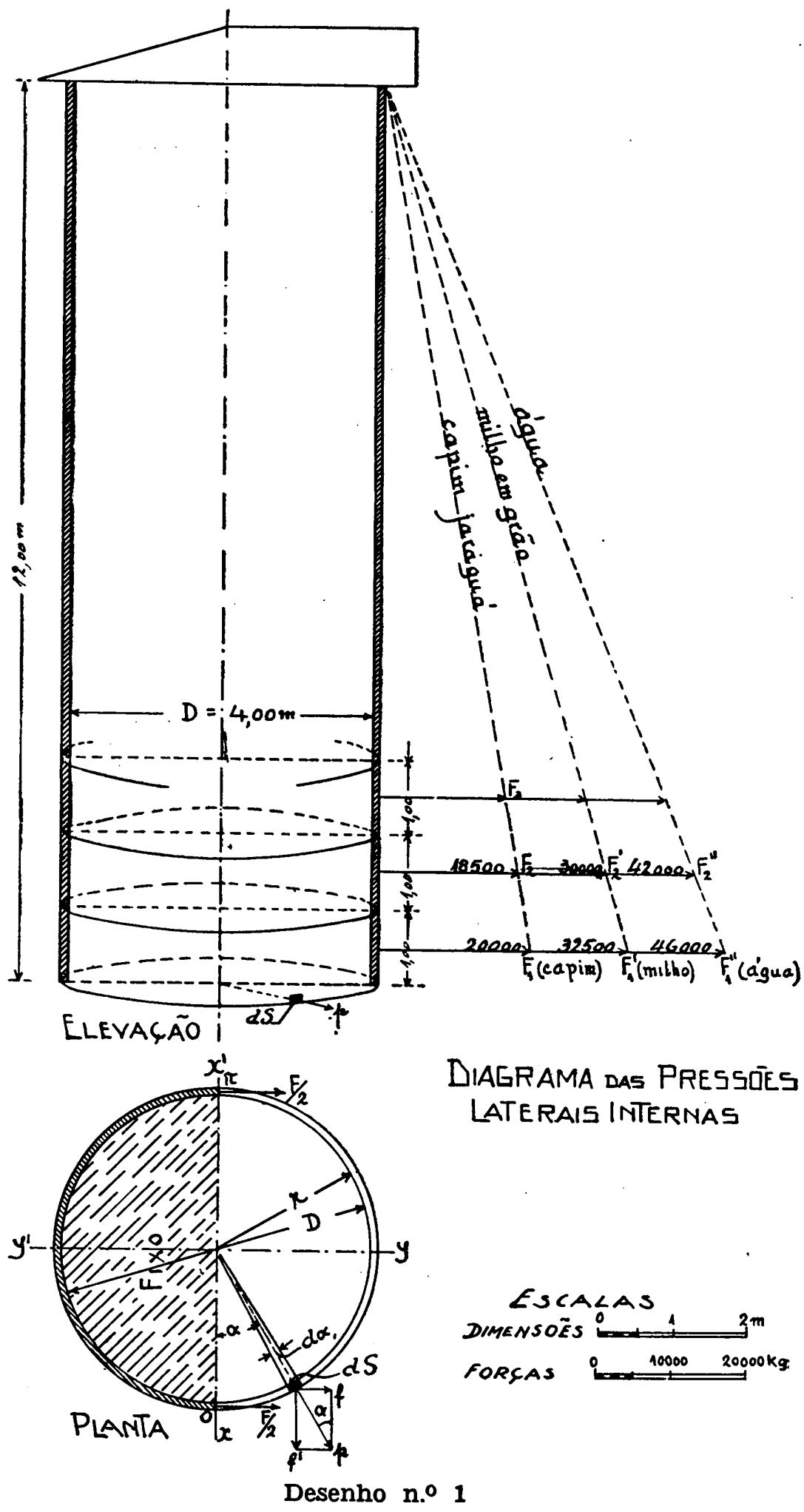


A força $F$, que procuramos, é, evidentemente, uma funçáo do ângulo $a$

$F=\int_{0}^{\pi} \mathrm{f} d \mathrm{~S} ;$ ora $\mathrm{f}=\mathrm{p} \operatorname{sen} a$ e $\mathrm{dS}=\mathrm{rd} a$, para $1 \mathrm{~cm}$ de altura

Então $\mathrm{F}=\int_{0}^{\pi} \mathrm{p} \mathrm{r} \operatorname{sen} a \mathrm{~d} a=\mathrm{pr} \int_{0}^{\pi} \operatorname{sen} a \mathrm{~d} a$, ou

$\mathrm{F}=\mathrm{p} r[-\cos ]_{0}^{\pi}=\mathrm{p} r[-(-1)-(-1)]=2 \mathrm{p} r=\mathrm{pD}$

Supre-se que uma metade é fixa e a outra tende a separar-se.

Exemplifiquemas para o caso da água; sendo, $H=12,00 \mathrm{~m}$, $\mathrm{D}=4,00 \mathrm{~m}$ e dS $=1 \mathrm{~cm}^{2}$, vem :

$p=0,01 \times 0,01 \times 12,00 \times 1000=1,2 \mathrm{~kg} / \mathrm{cm}^{2}$, no fundo do reservatório (ou silo), e normal ao elemento considerado; entăo, $F=1,20 \times 400=480 \mathrm{~kg}$ para uma faixa de $1 \mathrm{~cm}$ de altura, no fundo.

Para o cálculo da espessura da parede ou dos reforças vamos supor o reservatorio, ou silo, dividido em faixas horizontais de $1,00 \mathrm{~m}$ de alto, por exemplo. Para termos o valor da força F, em cada uma dessas falxas, tomamos, como altura, a altura média de cada uma das faixas, e calculamos os respectivos valores de $\mathrm{p}$. Assim para a primeira vem:

$F_{1}=1,15 \times 400 \times 100=46000 \mathrm{~kg}$ e para a segunda :

$F_{2}=1,05 \times 400 \times 100=42000 \mathrm{~kg}$ e assim por diante. Conhecidas essas forças, podemos calcular a espessura da chapa metálica ou o número de barras, e os seus diâmetros, etc. em cada faixa, conforme o tipo de construçăo, capazes de resistir a essas pressões ou forças $F_{1}, F_{2}$, etc.

Em vez de água poderíamos ter alcool, gasolina, óleo, etc.

A pressão p seria proporcional às densidades désses liquidos, isto é, aos seus pesos.

Mas, o que temos năo são liquidos, mas sim capim, millho verde, sementes ou um cereal qualquer que, năo sendo flúidos, vão, entretanto, exercer pressões laterais maiores ou menores, conforme as densidades ou pesas respectivos e segunda a maior ou menor tendencia que cada um desses materiais tem de se esparramar, isto é, essa pressăo vai depender do que chamaremas ângulo de atrito do material, formado pelo seu talude natural com a horizontal. Para os liquidos esse angulo 
de atrito é nulo, e para um material que se empilha à prumo é de $90^{\circ}$. Admitiremas que aquela pressão seja proporcional ao co-seno dêsse ângulo e normal ao elemento considerado.

Sendo $\Theta$ o angulo de atrito, $\mathbf{V}$ o volume correspondente ao elemento considerado e d a densidade do material ensilado, teremos : $\mathrm{p}=\mathrm{V}$ d $\cos \Theta$, fórmula que, além de muito simples é intultiva e racional, e se não der um resultado rigorasamente exato, pelo menos será bastiante aproximado. As ouitras fórmulas empíricas, também não são exatas, além de serem muito complicadas. Como $\cos 0^{\circ}=1$ e $\cos 90^{\circ}=0$, a fórmula é rigorosa para os dois casos limites : pressão máxima e nula, isto é, para líquidos e material que se empilha a prumo.

Para determinar o ânguio de atrito $\Theta$, fizemos experiências rápidas com alguns cereais e forragens verdes, derramando-as sôbre uma s uperficie horizontal, em forma de cones, com volumes de 2 e 5 litros apenas, tendo obtido os resultados indicados no quadro abaixo:

\begin{tabular}{l|c|c|c}
\hline Material & |angulo de atrito $\Theta \mid$ & co-seno & densidade \\
\hline Arroz em casca & $30^{\circ}$ & 0,87 & 0,61 \\
Milho em gråo & $22^{\circ}$ & 0,93 & 0,76 \\
Trigo em casca & $40^{\circ}$ & 0,77 & 0,80 \\
Café em cóco & $27^{\circ}$ & 0,89 & 0,40 \\
Semente de algodão & $48^{\circ}$ & 0,74 & $\mathbf{0 , 3 4}$ \\
Capim jaraguá & $40^{\circ}$ & 0,77 & $\mathbf{0 , 2 1}$ a $\mathbf{0 , 5 0}$ \\
Milho verde picado & $30^{\circ}$ & $\mathbf{0 , 8 7}$ & $\mathbf{0 , 2 5}$ a $\mathbf{0 , 6 0}$ \\
\hline
\end{tabular}

Experiências com maiores volumes devem ser feitas para cada caso concreto.

Exemplos : Vamos tomar o caso de um silo de madeira, desenho n. ${ }^{\circ}$, de $12,00 \mathrm{~m}$ de altura e $4,00 \mathrm{~m}$ de diâmetro, carregado, primeiramente, com milho em grão e, depois, com capim jaraguá.

\section{$10^{\circ}$ - com milho em grão :}

$\mathrm{p}=\mathrm{Vd} \cos \Theta=0,01 \times 0,01 \times 11,50 \times 760 \times 0,93 \mathrm{~kg}$

ou $\mathrm{p}_{1}=0,00115 \times 760 \times 0,93=0,813 \mathrm{~kg} / \mathrm{cm}^{2}$

$\mathrm{p}_{2}=0,00105 \times 760 \times 0,93=0,75 \mathrm{~kg} / \mathrm{cm}^{2}$ a $0,5 \mathrm{~m}$ acima do fundo e a $1,5 \mathrm{~m}$, respectivamente e assim por diante.

Para uma primeira faixa de $\mathrm{h}=1,00 \mathrm{~m}$ de altura, a contar do fundo, a fôrça que tende abrir o silo, será portanto: $F_{1}=p_{1} D h=0,813 \times 400 \times 100=32520 \mathrm{~kg}$ : Para uma segunda faixa: $F_{2}=p_{2} D h=0,75 \times 400 \times 100=30000 \mathrm{~kg}$ e assim por diante. 
A cada extremidade do plano diametral nas diversas faixas, correspondem as metades dessas fôrças, ou sejam : $16260 \mathrm{~kg}, 15000 \mathrm{~kg}$, etc.

Com a dispasição de táboas horizontais de 1", temos uma superficle util de $250 \mathrm{~cm}^{2}$ de cada lado, ou $500 \mathrm{~cm}^{2}$ ao todo, para cada metro de altura. Essa superfície pode suportar um esfôrço de tração de $500 \times 40=20000 \mathrm{~kg}$.

Para absorver a diferença de $12520 \mathrm{~kg}$, relativa à primeira falxa de $1,00 \mathrm{~m}$, teremos que a reforçar com duas cintas externas de ferro $\varnothing 3 / 4 "$ dispostas como se indica no desenho n. 8 . Dal para cima as cintas podem sər de diâmetros mais reduzldos, uma vez que a fôrça $F$ diminui com a altura.

Nota : Vemos, pelo que ficou dito, que a fôrça $F$ é proporcional à altura, ao diametro, à densidade do material ensilado e ao co-seno do ángulo de atrito $\Theta$. Unindo as extremidades, dos segmentos de retas que representam essas fórças, obteremas uma reta $F_{1} F_{2}$, com maior ou menor inclinação, conforme o material ensilado, como linha de distribuição désses esforças, o que permite obter, graficamente, o esfórço em cada plano horizontal, uma vez calculado em qualquer déles. Ver desenho n. 01 .

Em vez de cintas externas, podemos adotar, como se indica no desenho n. 0 , pares de tirantes internos, cruzados, em $90^{\circ}$, dois a dois, no mesmo plano horizontal, atravessando os pés direitos e esticados do lado de fora por melo de roscas e porcas sóbre arruelas.

Esses pares de tirantes săo deslocados de $30^{\circ}$ em relação ao imediato, no caso de serem 12 o número de lados do poligono da base, como no desenho que apresentamos.

\section{0 - com capim jaraguá :}

$\mathrm{p}_{1}=0,00115 \times 500 \times 0,77=0,443 \mathrm{~kg} / \mathrm{cm}^{2}$, digamos $0,5 \mathrm{Kg} / \mathrm{cm}^{2}$

e $\quad F_{1}=p_{1} D \mathrm{~h}=0,5 \times 400 \times 100 \mathrm{~kg}$,

ou $\quad F_{1}=20000 \mathrm{~kg}$ para a primeira faixa inferior de $1,00 \mathrm{~m}$.

Por onde vemos que só a madeira, com a disposição indicada, seria capaz de resistir àquela fórça. Por segurança, entretanto, colocaremos alguns pares de tirantes de ferro $\varnothing$ de $1 / 2$ " e de 3/8", uma vez que a madeira está trabalhando com carga especifica máxima admissfvel (táboas pregadas tôpo a tôpo sôbre os pés direitos).

NOTA: Os resultados, como já observamos, são sempne aproximados, pois dependem a!n densidade muito varìavel e do ângulo $\Theta$, também sujeito a oscilações. 
Ação do vento : Em tôda construção que se eleve a mais de quatro metros acima do solo, o vento provoca esforços que devem ser levados em consideração, pois podem afetar a sua estabilidade.

Náo só a superestrutura, como os alicerces e fundaçōes devem ser previstas para oferecer a necessária resistência a tais esforços.

A pressão que o vento exerce sôbre uma superfície normal à sua direção é proporcional ao quadrado da sua velocidade. Por al vemos como aumenta essa pressão à medida que cresce a velocidade.

Para um vento de $40 \mathrm{~m} / \mathrm{seg}$ corresponde uma pressão de $200 \mathrm{~kg} / \mathrm{m}^{2}$ (vendaval) que adotaremos para mostrar o seu efeito sóbre um silo vazio, de madeira, e sôbre um silo, tambem vazio, de alvenaria de tijolo.

1.0) silo de madeira - As experiências levaram à conclusão que para superfícies cilíndricas, a pressão é dada pela fómula

$$
\mathrm{Fv}=\frac{2}{3} \mathrm{p} \mathrm{D} \mathrm{H} \text {, sendo } \mathrm{p} \text { a pressão por } \mathrm{m}^{2} \mathrm{em} \mathrm{kg}, \mathrm{D}
$$

o diâmetro externo, em m e $\mathbf{H}$ a altura, também em $\mathbf{m}$.

Vamas supor, primeiramente, que o silo está apenas assentado sôbre a base de alvenaria, sem ligaçåo alguma com esta. logo

No nosso caso $\mathrm{D}=4,40 \mathrm{~m}, \mathrm{H}=12,00 \mathrm{~m}, \mathrm{p}=200 \mathrm{~kg} / \mathrm{m}^{2}$,

$$
F v=\frac{2}{3} 200 \times 4,40 \times 12,00=1600 \times 4,40 \approx 7000 \mathrm{~kg}
$$

O pêso do silo vazio, é, aproximadamente $P=7000 \mathrm{~kg}$.

O centro de aplicação da resultante da ação do vento e o centro de gravidade do silo coincidem aproximadamente, neste caso, com o seu centro geométrico ou centro de figura. A resultante de $\mathbf{F v}$ e $\mathbf{P}$ cai fora da base de sustentação, em MM', como se vê no desenho n.o 2.

Isso quer dizer que o silo tombaria, pela certa, se năo estivesse solidamente ancorado ao pêso da base, formado pəlo bloco de alvenaria, acrescido do pêso da terra que se lhe sobrepõe, antes mesmo do vento atingir aquela velocidade. A mesma conclusão chegaríamos se examinássemos as momentos daquelas fôrças.

Para evitar que o. silo tombe, com a ação do vento, temos 


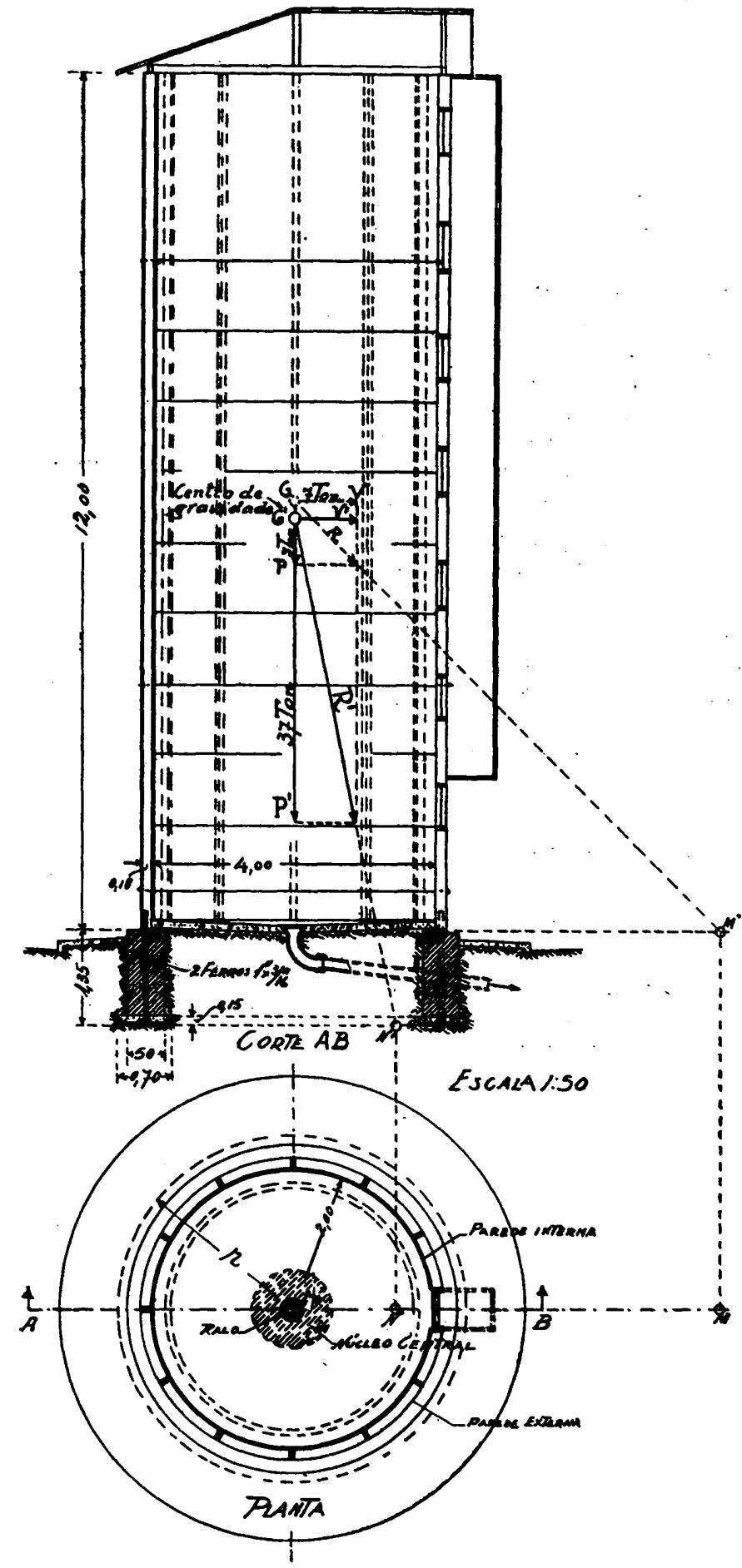

ACSAOD DO VENTO EM um SILODCMADEIRA. (vasio)

Desenho n.o 2 
que aumentar o seu peso, tornando-o solidário com a base, por meio de barras de ferro ancoradas no. bloco de fundaçáo. Com ésse dispositivo o peso - do silo. vazio passa a ser $P^{\prime}=37000 \mathrm{~kg}$, o valor de $\mathrm{Fv}$ continua o mesmo, bem como o seu ponto de aplicação.

O centro de gravidade, que é o ponto de aplicałáo de P', é deslocado para baixo. Por comodidade e uma yez que para ? nosso estudo năo faz grande diferença, supomos que os pontos de aplicaçáo dessas forças continuam, coincidindo.

A nova resultante $R^{\prime}$ de $\mathbf{P}^{\prime}$ e Fv cai agora dentro da bas de sustentaçáo em $\mathrm{NN}^{\prime}$ embora fora do núcleo central, que, neste caso, é, um cículo de raio igual a quarta parte.do circulo externo da base. Isso quer dizer que, sóbre a base, val haver esforças de dois sentidas, compressão e traçăo. Nâo há, contudo, mais perigo do silo tombar, uma vez que a ligaçáo da parte superior com a base esteja estabelecida por meio de barras de ferro.

\section{0 - silo de alvenaria de tijolo: Desenho n.0 4}

Pêso do silo vazio $P=100$ ton.

Ação do vento $\mathrm{Fv}=6$ ton. A resultante cai dentro donúcleo central. Náo há perigo de tombar.

Note-se que o centro de gravidade năo coincide com o ponto de aplicação da açăo do vento, mas supusemos haver essa colncidéncia, por comodidåde, sem inconvenientes, na prática.

Para se ter com maior precisăo a posição da resultante do pêso do silo e da ação do vento deveríamos supor o silo dividido em faixas horizontais e achar a resultante em cada faixa e depois construir o polfgono dessas fôrças.

\section{REQUISITOS IMPORTANTES}

Um silo deve ser impermeável à umidade em tódas as direçōes e ao ar lateral e inferiormente, pois este viria prejudicar a forragem ensilada, tornando-a nociva ao gado. Não ha inconveniente, entretanto, que a superficie superior recej3, ar através do telhado.

Deve ser incombustível e năo sujeito ao ataque de ratos. Os silos de madeira apresentam éstes inconvenientes.

Deve ainda ser de fácil conservação. 

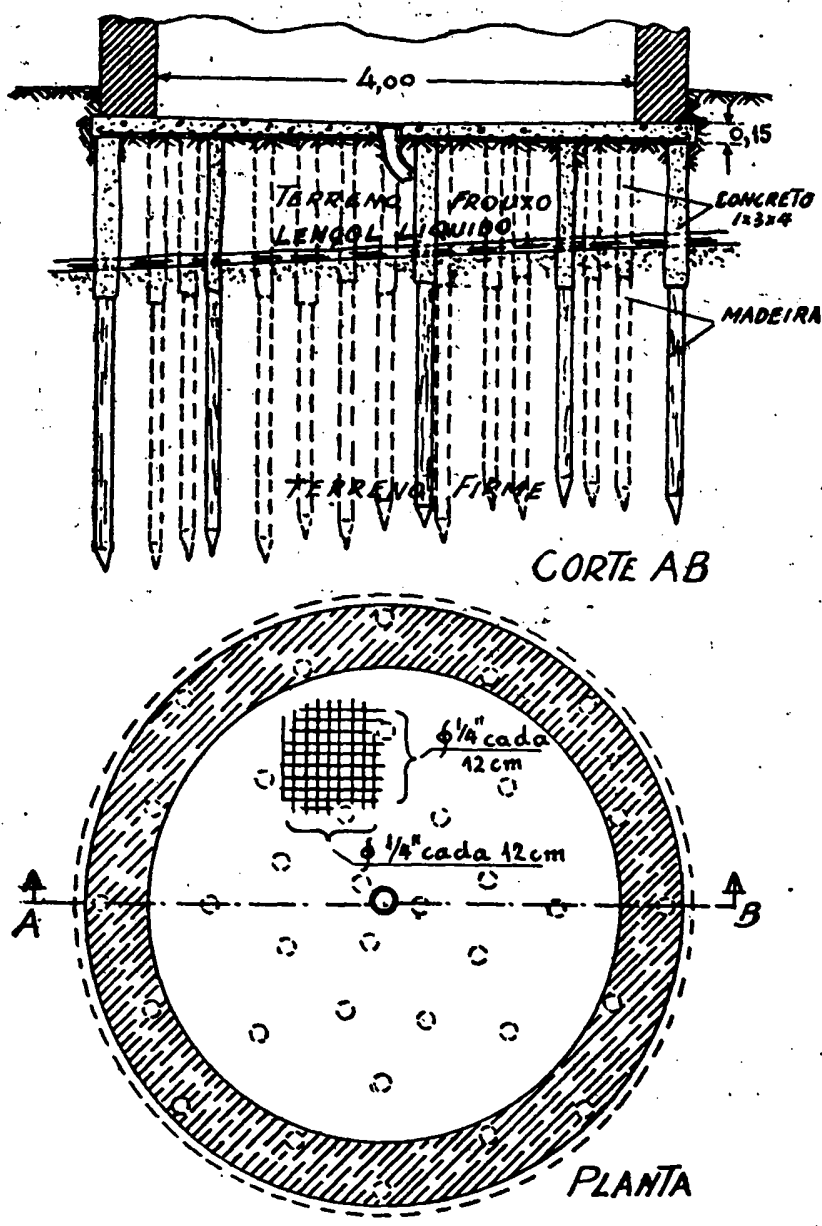

Base sobre Estacas de Madeira Desenko n.0 3

\section{PARTES ESSENCIAIS DO SILO}

Fundacōes e alicerces : Se o terreno for firme ou consistente, podendo trabalhar, pelo menos, $2 \mathrm{~kg} / \mathrm{cm}^{2}$ e se esti- 
ver a menos de $2,00 \mathrm{~m}$ de profundidade, năo há necessidada de preparo especial de consolidação. Basta ser bem socado.

A sapata do alicerce deve ser de concreto, de preferencia armado com barras de ferro de $\varnothing 1 / 4 "$ e $\varnothing 3 / 8 "$ ", para uma melhor distribuição da carga sôbre o terreno.

$O$ alicerce deve ser de 2 tijolos de espessura.

Se o terreno firme estiver a uma profundidade superior a $2,00 \mathrm{~m}$, recorre-se a estaqueamento.

As estacas podem ser de madeira, agulhas de concreto sem armaçăo ou de concreto armado pré-moldado.

Se as estacas forem de madeira, deve-se ter o cuidado de cravá-las até que as cabeças fiquem abaixo do lençol líquido, para evitar o ataque de fungos ou bacterias (podridāo).

Estas para viver precisam de 4 elementos: oxigenio (ar), alimento (a madeira) temperatura conveniente $\left(0^{\circ}\right.$ a $\left.60^{\circ}\right)$ e umidade (água). Com aquéle cuidado ficam fora do contato do ar e assim, faltando um dêsses elementos, năo poderão se desenvolver. Ver desenho n.0 3.

Depois de batidas as estacas, a uniformidade de altura se obtem com cabeçotes de concreto, sôbre as quais estende-se a placa de fundaçăo.

As agulhas de concreto são obtidas abrindo-se no terreno furos com trados ou brocas de 10 a $20 \mathrm{~cm}$ de diametro e enchendo-os com concreto $(1 \times 3 \times 5)$ a sêco, bem socado.

Para um silo de alvenaria de tijolo, até 100 ton de capacidade bastariam 16 estacas para o peso do silo e mais $16 \mathrm{pa-}$ ra a carga, isto é, 32 ao todo, supondo que cada estaca passa suportar uma carga de 6 a 8 toneladas.

Piso : Deve ser liso, de preferencia de concreto, com armação inferior e superior nos dois sentidas, impermeável, com queda para um ralo de escoamento do sumo e águas de chuva e de lavagem.

Cava : Com o fim de aumentar o volume e a estabilidade, os silos podem ser dotados de uma cava, cujo fundo não deve ficar a mais de $2,00 \mathrm{~m}$ abaixo do nivel do terreno, para não dificultar a remoção da forragem. Deve ser muito bem impermeabilizada.

Impermeabilização: Um cuidado especial que se deve ter é com a impermeabilização, não só do piso e das paredes da cava, como também com a face externa das paredes do corpo do silo, em virtude de chuvas de vento continuadas.

Antes de se concretar a lage do piso é convenientia Impermeabilizar o terreno. 
A impermeabilizaçăo da cava deve ser feita pela face externa, de preferencia.

Nos silas subterraneos a impermeabilizaçáo é, geralmente, feita internamente, o que năo é recomendável.

Uma bôa impermeabilização se obtém com duas demãos de revestimento de areia e cimento, $1 \times 3$, ao qual se tenha adicionado um impermeabilizante adequado (Vedacit; Bianco, Sika, etc.), pintando-se depois a superficle com tintas impermeabilizantes apropriadas.

Uma ótima tinta para esse fim é o asfalto a quente misturado com gazolina, em partes iguais, e que se aplica com um pincel ou brocha comum sóbre a superficie limpa e seca.

Paredes : Quando são só de alvenaria de tijolo, na parte inferior a espessura é de 2 tijolos, reduzindo-se para $11 / 2$ e terminando em cima com 1 tijolo de espessura, sempre assentados com argamassa de 1 de cal, 1 de cimento e 6 de areia.

Quando de alvenaria mista, concreto e tijolo, a espessura dos alicerces é de $11 / 2$ tijolo, tendo 0 resto 1 tijolo de espessura apenas. Sendo só de concreto armado a espessura da parede val de 7 a $15 \mathrm{~cm}$.

Quando de madeira convém seja de parede dupla, interna e externa, podendo esta ser um simples revestimento de táboàs finas ou mesmo de estuque, sóbre tela metálica e tarugos de madeira, com o fim principal de evitar a penetração da umidade, contribuindo isto também para melhorar o aspeto desses silos.

Nas silos metálicos, ou de cimento-amianto, as paredes podem ser simples, com as chapas remontadas.

Estrutura e reforços: Nos silos de alvenaria de tijolo a estrutura é construida simplesmente pela parede, alicerces e placa de fundação.

Nas silas de alvenaria mista, tijolo e concreto armado, a estrutura é formada pelos pllares e cintas de concreto armado.

Os sllos de madeira, metálicas e de chapas de cimentoamianto teem a estrutura constituida pelos pés-direitos, cambotas, traves e peças de contravento.

Para resistir às pressరes internas laterais, devidas ao peso do material ensilado, lança-se mão de cintas metálicas de refórço; convenlentemente calculadas, e qư são ajustadas, externamente, de encontro as pés-dreitos e apertadas por melo de parafusos especiais.

Essas cintas são geralmente de ferro redondo, de bitola va- 
riando de 1" a 3/8", conforme o caso, alojado em ranhuras feitas nas cambotas, quando estas existem.

Quando os pés-direitos são de madeira, as cintas podem ser substituidas, com economia, por pares de tirantes, cruzadas em $90^{\circ}$, no mesmo plano horizontal, com as pontas atravessando os pés-direitos e apertadas contra êstes por melo de parafusos, porcas e arruelas, conforme já fol mencionado.

Sendo de 12 o número de lados do polígono da base, os pares de tirantes são deslócados de $30^{\circ}$, cada dois pares consecutivos.

esses tirantes văo senđo colocados de baixo para cima, à medida que se enche o silo é retirados, de cima para baixo, à medida que se descarrega, com tóda a facilidade, em nada atrapalhando as operações de carga e descarga.

Contraventamento : E' indispensável quando a estrutura é constituida por pés-direitos de madeira ou de ferro, para que o silo năo se deforme. São peças ligando os pés-direitos, de modo a formar triângulos indeformáveis.

Telhado: Pode ser constituido por uma armação de madeira ou metálica, formando um conjunto de tesouras com um só pendural e uma cobertura que pode ser de telhas comuns, de zinco, de madeira ou de chapas de cimento-amianto. Os silos de alvenaria podem também ser cobertos por uma só peça de concreto armado.

E' sempre muntdo de um sótão ou alçapão para dar acesso aos operários no interior do silo.

Havendo necessidade do sótão ficar fechado para evitar a entrada de chuva, é preciso deixar frestas de ventilação, na parte superior da cobertura, para saida dos gazes.

Revestimento : Pode ser comum, mas de preferência impermeabilizado, tanto o externo, como o interno. Neste devese adicionar sempre cimento.

Esgôto : E' sempre necessário se instalar um ralo ligado ao esgôto, no piso do silo, para dar saida ao sumo, águas de chuva e de lavagens. Pode ser ligado a um poço absorvente sob o piso, ou melhor, ter saida para fora por meio de tubas de bitola de 3" ou 4", metálicas, de cimento-amianto, manilhas de barro ou canaletas de tijolos.

Escada : Os silos elevados e os subterraneos circulares são sempre munidas de escada fixa para facilitar o acesso dos operários. 



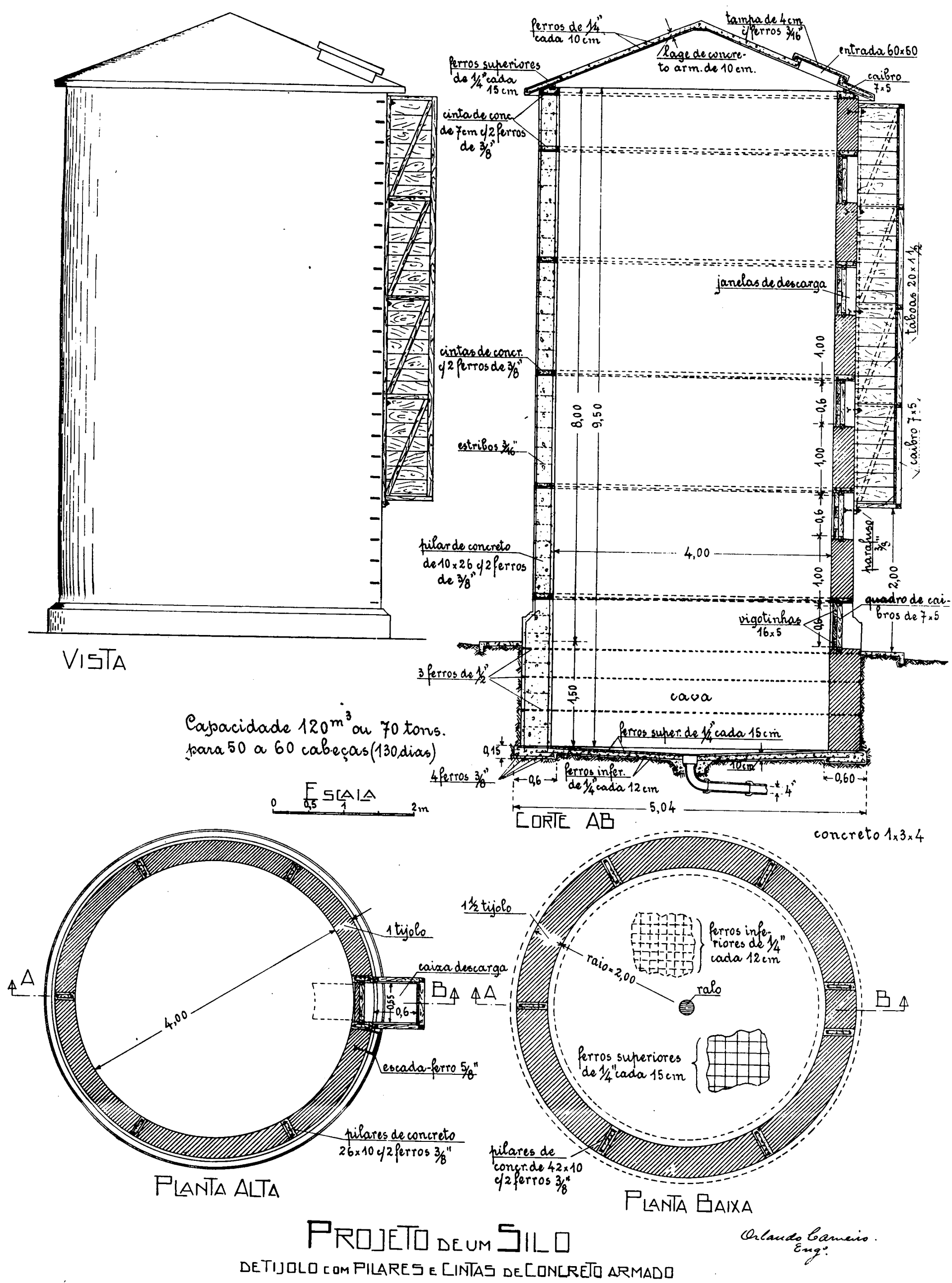




\section{DESCRIÇAO DOS DIFERENTES TIPOS PROJETADOS}

Seguindo a ordem da classificação geral, que atrás fizemos, passaremos a descrever, primeiramente, o

Silo de alvenaria de tijolo : Desenho n.o 4. E' um silo elevado, sem cava, destinado à forragem verde, de construção simples e barata e de fácil conservação.

O alicerce, de dois tijolos de espessura, repousa sôbre uma sapata de concreto armado com 3 ferros $\varnothing$ de $5 / 16 "$ " estribos de $3 / 16 "$, cada $30 \mathrm{~cm}$.

O terreno deve ser previamente bem consolidado.

A parede sobe com a espessura de 2 tijolos até $1,50 \mathrm{~m}$ de altura, reduzindo-se para $1 \frac{11 / 2}{2}$ até $5,00 \mathrm{~m}$ e depois para 1 tijolo até em cima.

Os tijolos devem ser assentados com argamassa de cal, areia e cimento.

A armação do telhado foi projetada para cobertura com telhas canoas ou francesas.

As janelas de descarga são guarnecidas com um quadro de calbros de encontro ao qual se apoiam os sarrafoes de $3 \mathbf{x}$ $12 \mathrm{~cm}$. Tanto os caibros do quadro, como os sarrafões devem ser aparelhados, afim de que haja perfeita adaptação, o que se consegue melhor com junta de borracha ou de papelão alcatroado.

Com as mesmas espessuras de paredes, pode-se ampliar o diâmetro até $5,00 \mathrm{~m}$ e a altura até 12,00 , se houver necessidade de maior capacidade.

Silo de alvenaria mista : Desenho n.o 5 . E' também um silo elevado, provido de cava, destinado a forragens verdes.

A designação de alvenaria mista se justifica por ser uma construção de tijolos reforçada com pilares e cintas de concreto armado, como se ve no respectivo desenho. As paredes da cava são cintadas com alguns ferros redondos para melhor resistir às pressőes laterais internas.

A placa de concreto da base foi projetada com espessura mais reduzida que a do t:po anterior, porém com armação dupla.

Dessa base nascem os pilares de refôrço, devendo ficar bem ancorada, no seu seio, a ferragem vertical dos mesmos.

o piso deve ser liso e oferecer declividade de $2 \%$ a $3 \%$ para o ralo de escoamento do sumo e água de lavagem ou de chuva.

Com os reforços indicadas as paredes podem ter a espes- 
sura reduzida a um tijolo e meio na cava e a um tijolo na parte elevada, mas sempre assentados com argamassa de cal, areia e cimento.

Havendo necessidade de ampliar as dimensões, para se obter maior capacidade, deve-se ter o cuidado de aumentar também, convenientemente, os pilares e cintas de reforço.

A cobertura fol projetada em concreto armado, para evitar a complicaçáo do madeiramento e do telhado de forma circular e o inconveniente de ser preciso cortar muitas telhas.

Uma lage de concreto armado resolveu, neste caso, o f... blema da cobertura de modo simples e rápido, como se indica no desenho. Além de ser de duração ilimitada, é solução, talvez, mais económica.

Para evitar que as paredes do silo sejam afetadas pelas dilataçōes e contrações que a lage de cobertura sofre devido às variações de temperatura, faz-se essa lage repousar sobre segmentos de caibros encaixados na cinta de concreto armado com que se respalda a parede do silo. Para isso, esse segmentos de madeira são chanfrados, na parte superior, em rampa, de acôrdo com a inclinaçáo da lage de cobertura.

o sótão de entrada é substituido por uma abertura de forma circular ou retangular, praticada junto a parede e calxa de descarga e por onde possa entrar uma pessoa. fício é protegido por uma tampa de madeira, por uma chapa metálica, ou por uma pequena lage de concreto armado, como se indica no projeto.

Desenho n.0 6 - E' um silo do mesmo tipo que o anterior, porém de maior capacidade e, por isso, mais reforçado. zinco.

A armação da cobertura foi projetada para chapas de

As janelas de descarga são guarnecidas com quadros de ferro $T$ ou $L$, embutidos em concreto. $O$ fécho é constituido por uma chapa de madeira ou de ferro nervurado, que se adapta ao quadro, com junta de borracha ou de papeláo alcatroado, pelo lado de dentro. Um parafuso de chamada, acionado por fora, permite uma perfeita adaptaçáo do fecho.

Silo de concreto armado. Desenho n.o 7 - E' um silo elevado, com cava, para forragens verdes.

A construção de silas de concreto armado torna-se simples e económica, quando se adotam formas apropriadas.

Na construção da cava, isto é, da parte que fica abaixo da superficie do terreno circundante e que năo deve ter profundidade superior a $1,50 \mathrm{~m}$, para náo dificultar a retirada da 
$175 \mathrm{~m}^{3}-90$ cabecus -150 dias

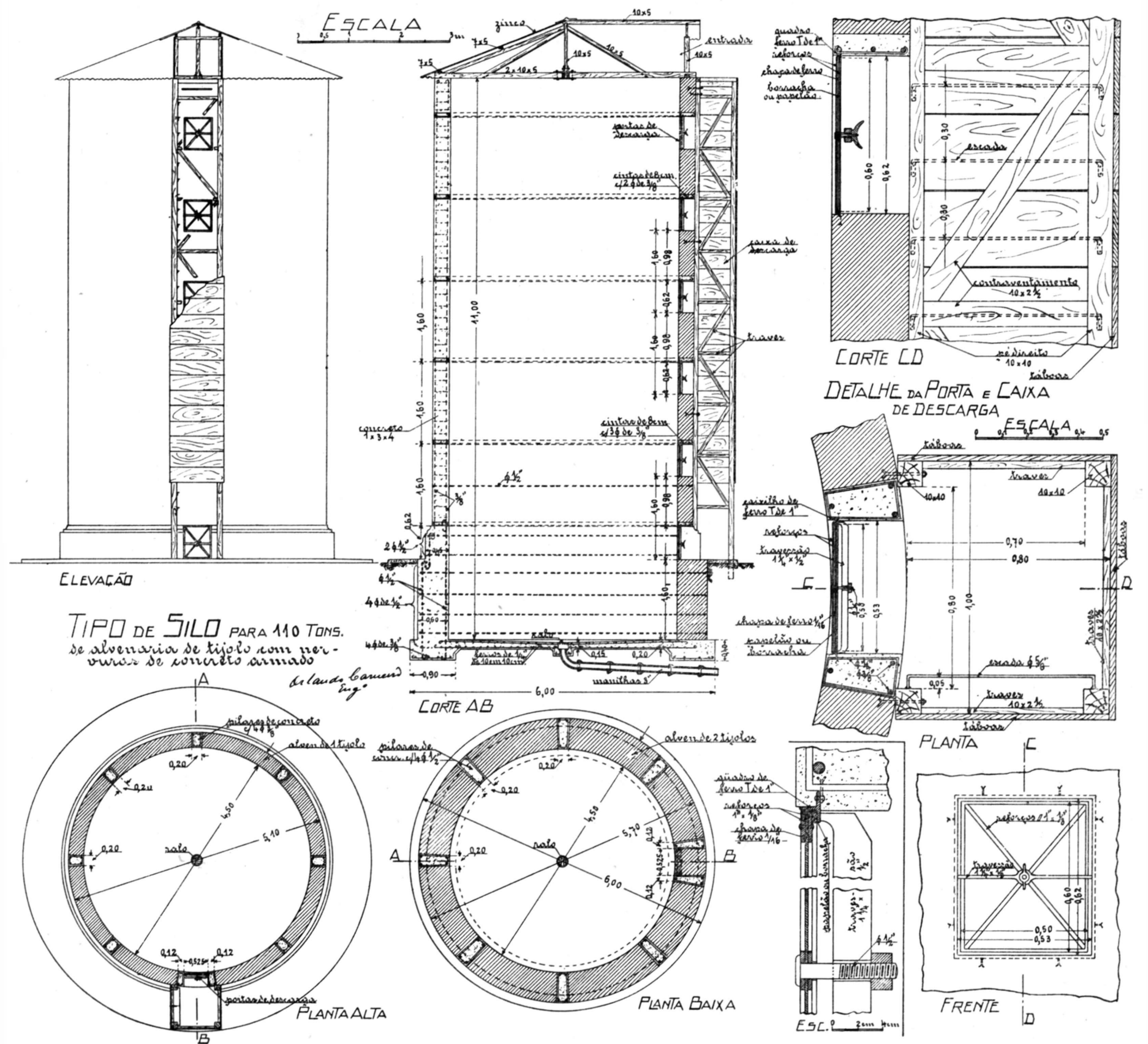

Desenho n.o 6 
forragem, o proprio terreno serve de forma externa. O terreno sóbre o qual repousa a base deve ser muito bem consolidado.

O lançamento do concreto sôbre a base será feito de uma só vez, e, para estabelecer ligaçăo desta com a parede, colocam-se verticalmente, de $50 \mathrm{em} 50 \mathrm{~cm}$, barras de ferro $\varnothing$ de $3 / 8$ ", com $50 \mathrm{~cm}$ de comprimento, aproximadamente.

O piso tem inclinação de $2 \%$ para o centro, onde se instala um ralo ligado ao esgoto.

Ao iniciar nova concretagem, convém limpar bem com uma escova de aço a junta de ligaçăo.

Fôrmas - As fôrmas têm $90 \mathrm{~cm}$ de altura, de modo yue se possa concretar de cada vez $80 \mathrm{~cm}$, devendo os outros $10 \mathrm{~cm}$ ficar encaixados na parte de baixo, já pronta, da parede do silo. Ver desenho n.o 7 .

O suporte de madeira da forma interna é feito de acórcio com a flg. 2, consistindo num conjunto de 3 peças formadas, cada uma, por duas cambotas A, B, C ou C', ligadas por montantes D, E, F.

Para cortar exatamente as cambotas, risea-se no chăo uma circunferência com o ráio interno que vai ter o silo.

As cambotas C', com uma parte reta, são usadas na vertical das portas, para que estas possam ser retas.

Montadas as 6 peças do suporte de madeira, formam-se as suas supe:ficies cilindricas com uma chapa de forro de $1 \mathrm{~mm}$ de espessura. A seguir faz-se a ligaçăo de todas elas, como se ve na fig. 3 , por melo de parafusos $J$ e travessas de madeira $H$ de $75 \times 15 \mathrm{~cm}$.

As duas cunhas de madeira $G$ facilitam a desmontagem da forma.

Uma vez frouxa, a forma é elevada verticalmente, sendo o seu moviinento orientado por melo de guias que passam nos orificios existentes no centro das cambotas. Essas guias vaj se preganco umas as outras. De $80 \mathrm{em} 80 \mathrm{~cm}$ fa\%-se nelas um furo de 1,2" onde se introduzem cavilhas que sustentain a forma. Abalxo da forma, executa-se o contraventamento das guias, convrurme indica a fig. n.0 5 .

A forma externa é formada por duas chapas de $11 / 4 \mathrm{~mm}$ de espessura, com $90 \mathrm{~cm}$ de largura e $5,5 \mathrm{~m}$ de comprimento, as quais se fixam as ganchas $M$ e $N$ da fig. 6.

A colocaçáo da forma externa é feita como $a$ interna, apoiando-se $10 \mathrm{~cm}$ contra a parte inferior da parede já construida e a parte superior na fôrma interna, por meio de es- 
paçadores de madeira de $15 \mathrm{~cm}$, que se vão retirando à medida que se enche a forma.

$O$ aperto da forma se faz com o auxilio de 6 parafusas $P$, indicados nas figs. 3 e 6.

As fôrmas das portas estão indicadas na fig. 7 e para facilitar a sua retirada todos os lados são inclinados. ligeiramente, dando uma diferença de $5 \mathrm{~mm}$ entre as faces da parede

Ferragem - As barras verticais são de 3/8" e distanciadas sempre de $76 \mathrm{~cm}$; as horizontais, são da mesma bitola e o seu afastamento está indicado no desenho para a altura de $10 \mathrm{~m}$.

Para alturas diferentes, o espaçamento d das barras horizontais, de $3 / 8$ ", vai indicado na tabela seguinte:

\begin{tabular}{r|c}
$\begin{array}{c}\text { Altura do silo } \\
\text { em m }\end{array}$ & $\begin{array}{c}\text { Espaçamento d das barras } \\
\text { horizontais em cm }\end{array}$ \\
\hline $\begin{array}{rrr}0 \\
4,2 \text { a }\end{array}$ & \\
6,0 a 7,6 & 60 \\
7,6 a 9,0 & 45 \\
9,0 a 10,5 & 40 \\
10,5 a 12,0 & 35 \\
\hline
\end{tabular}

Os demais detalhes da ferragem estão indicados no des:nho respectivo.

Depois de retiradas as formas, corrigem-se as irregularidades com argamassa de cimento e areia a $1 \times 2$.

Caixa de descarga - Pode ser construida de madeira ou de concreto armado, tendo, neste caso, cinco ferros de $3 / 8$ " verticais e ferros de $3 / 8$ " horizontais, espaçados de $50 \mathrm{~cm}$, bem ancorados, em gancho, na parede do silo, conforme indicamos no desenho mencionado.

Cobertura - Pode ser um telhado comum, de zinco ou de telhas de barro, provido de um sótão de entrada. Para este caso as respectivas detalhes estão indicados nos desenhos anterior e seguinte.

Querendo-se fazer a cobertura com concreto, deve-se observar as disposiçōes indicadas neste desenho n.0 7.

NOTA: Os ferros acima menclonados sáo redondos. 
Capacidade - A tabela anexa nos permite saber qual deve ser a altura total de um silo, de $3 \mathrm{~m}$ de diametro interno, para nêle se armazenar um determinado volume de forragem, indicando também o peso total desta, supondo que $1 \mathrm{~m}^{3}$ da mesma pese 600 a $700 \mathrm{Kgs}$.

\begin{tabular}{c|c|c}
\hline Altura em m & Capacidade em $\mathrm{m}^{3}$ & Pêso em tons. \\
\cline { 1 - 2 } 6 & 43 & \\
\hline 7 & 50 & 30 \\
8 & 57 & 35 \\
9 & 64 & 40 \\
10 & 71 & 45 \\
11 & 78 & 50 \\
12 & 85 & 55 \\
\hline
\end{tabular}

Nota - As indicações acima, ræferentes à construçăo de silo de concreto armado, foram obtidas do Boletim de Informaçōes da Associação Brasileira de Cimento Portland.

Silo de madeira - Desenho n. 8 Este é o projeto de um sllo elevado com cava, de grande capacidade, que pode servir para forragens verdes ou para armazenar sementes de algodão. O seu preço é elevado em vista dos reforços necesśários.

Nas locais onde a madeira é de facil obtenção e de preço năo excessivo a construção de silos ou de celeiros com esse material torna-se prática e rápida, com bons resultados.

O nosso desenho indica com clareza suficiente o modo de construf-los. Para diametras superiores a $10 \mathrm{~m}$ convém adotar a forma de um poligono regular de 16 ladas, em vez de 12 lados, como é a do nosso projeto.

Para se abrir as janelas de descarga, desprega-se primeiramente os mata-juntas, dobra-se a parte inferior dos calbros que formam a corrediça e retira-se a vigota de baixo. As outras descem naturralmente, e são removidas depois, cada uma por sua vez.

tisses mata-juntas, removiveis, das janelas, são pregados para evitar a fuga do gás carbónico que concorre para a conservação do material ensilado ou armazenado.

As cintas de ferro são indispensáveis para evitar que o silo se abra devido à pressão do material af guardado e devem ser munidas de dois esticadores, cada uma. 
As cambotas podem ser mantidas no lugar por meio de tacos ou chapuzes. mente.

A cava deve ser muito bem impermeabilizada interna-

Quando são destinados somente ao armazenamento de caroço de algodão ou de cereais a cava pode ou não deve existir, nascendo então, neste caso, a construção do rez do chão, sôbre base de concreto.

Devem ser pintados, pelo menos, de 3 em 3 anos para a sua boa conservação.

A madeira empregada deve ser de primeira qualidade.

Para se poder cortar com exatidão as cambotas e vigas, convém riscar no chão, ou sôbre a base de concreto, a forma das mesmas, marcando a posição das pés-direitos.

A parte interna das vigas deve ser um pouco maior que e externa, para encontrar resistencia nos encaixes feitos nos pés-direitas. Estes devem ser solidamente presas com barras ou chapas de ferro, à base, para evitar alguma surpreza devido à ação do vento, quando o silo estiver vazio.

Algumas informações sôbre êste tipo de silo devemos à gentiliza do Engenheiro Guaraci Di Paravicini Torres, da firma Anderson Clayton.

Desenho n.' 9 - E' um silo de menor capacidade, sem cava, porém, de construção bem mais simples que a do precedente, e, porisso, mais económico. Pode servir para forragem verde, para caroço de algodão e até mesmo para grăos secos.

A estrutura é constituida por 13 pés-direitos de $18 \times 8 \mathrm{~cm}$ ancorados no bloco da sapata por melo de ferros chatos de 2" x 1/4". . ste dispositivo tem por fim evitar que o silo tombe, quando vazio, devido à ação do vent.o.

As emendas dos pés-direitos são reforçadas com chapas e parafusos de ferro. Os pés-direitos são contraventados por meio de peças de madeira de $12 \times 6 \mathrm{~cm}$, como se indica no projeto.

A parede interna principal é formada por táboas com juntas de macho e fêmea, de $20 \times 2,5 \mathrm{~cm}$, dispostas horinzontalmente e pregadas sóbre os pés-direitos do lado de dentro. Náo convém usar táboas de maior largura para evitar empenamento.

A cobertura é feita com táboas dispostas horizontalmente em escamas.

As janelas e caixa de descarga são idênticas às dos projetas anteriores.

O refórço é constituido por pares de tirantes de ferro, terminadas em roscas, cruzadas dois a dois, no mesmo plano horizontal, atravessando os pés-direitos e apertados de en- 


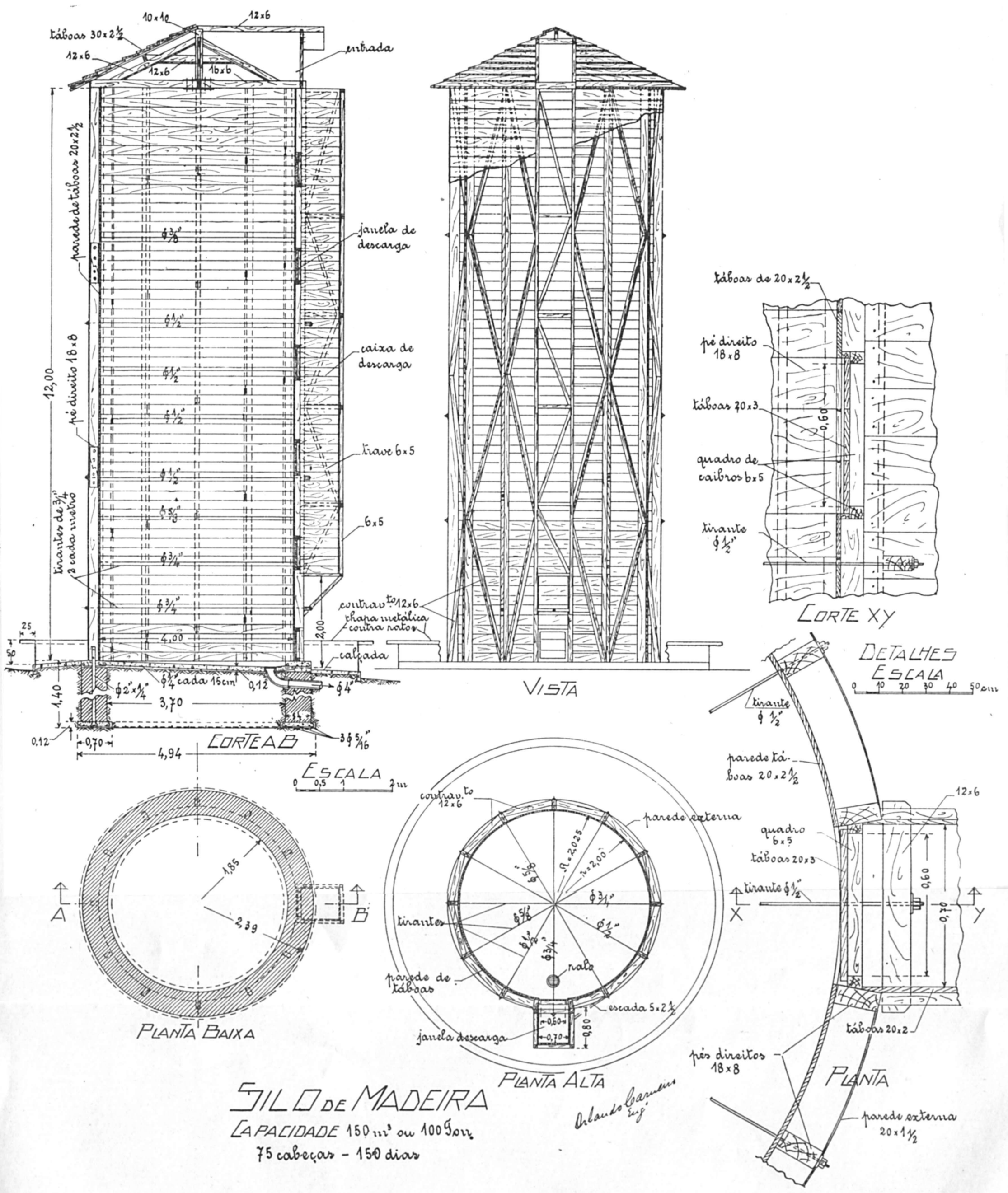


contro a êstes, do lado de fora, por meio de parafusas e arruelas.

Cada dois pares de tirantes consecutivos são deslocados de $30^{\circ}$. O número de pares de tirantes e à sua bitola dependem das dimensóes do silo e do material com que o mesmo é carregado, como vimas no cálculo das pressões laterais internas.

Para nåo atrapalhar a carga e a descarga esses tirantes são colocados de baixo para cima a medida que se carrega o silo e retirados de cima para baixo quando se procede a descarga, conforme já foi dito atrás.

Uma parede externa, constituida de táboas mais finas, pregadas hcrizontalmente sóbre os pés-direitos, do lado de fora, além de proteger a parede interna principal, contra a chuva e sol, concorre para um melhor aspecto da construção.

Neste projeto o ralo do p!so foi colocado junto a parede, ao lado da primeira janela de descarga, com o fim de economizar manilhas e para facilidade de reparos.

A proteçáo contra os ratos é constituida por uma chapa metálica de $0,50 \mathrm{~m}$ de altura circundando o silo, com rebordo de $0,25 \mathrm{~m}$ para fora.

Para se montar com exatidăo os pés-direitos riscam-se sóbre a base as circunferências interna e externa das paredes, marcando-se previamente a posiçăo de cada pé-direito.

Silo metálico - Desenho n.o 10. E' um silo elevado, sem cava, destinado a forragens verdes ou a grăos secas e sementes.

A sua estrutura é constituida por 13 pés-direitos de ferro $I$, ou duplo $T$, de $12 \mathrm{~cm}$, bem ancorados na sapata de fundação, para se opor eficazmente à açăo do vento quando o silo estiver vazio.

Astes pés-direitos são travados por melo de ferro em L de 2" x 1", como se indica no projeto.

A parede interna principal, é formada de chapas de ferro preto ou galvanizado de $2 \mathrm{~m}$ por $1 \mathrm{~m}$, remontadas de $2,5 \mathrm{~cm} \mathrm{e}$ rebitadas umas sóbre as outras de modo que a parte superior da chapa de baixo fique por dentro da chapa de cima.

o raio da face interna dos pés-direitos fol calculado de modo que o comprimento da chapa de $2,00 \mathrm{~m}$, dê Justo, sem corte, para dois pés-direitos.

Para maior diametro e maior altura as chapas da parede devem ter maior espessura (números mais balxos).

As janelas de descarga foram projetadas de modo análogo às anteriores.

A calxa de descarga é feita com chapas de ferro reforçadas com ferro em cantoneira de 1" 1 1" has dois cantos de 
fora. As dimensões da seç̧ão dessa caixa devem ser de modo que o comprimento da chapa de $2,0 \mathrm{~m}$ seja aproveitado por inteiro.

A armação do telhado é feita com ferros T de 11/2" $\times 1 \frac{1}{2}$ " e a cobertura com chapas n. 24 .

Hste tipo de silo dispensa parede externa. A sua conservação é um pouco dispendiosa, pois exige pintura geral cada três ou quatro anos. Sua duração é ilimitada, quando bem conservado.

Podem ser pré-fabricados e montados rapidamente no local onde deve ser instalado.

Silo de Cimento-Amianto - Desenho n. 11. E' um silo elevado, sem cava, destinado a forragens verdes, anexo a um estábulo para 25 cabeças.

As paredes são de chapas onduladas de cimento-amianto.

A sua estrutura é constituida por 12 pés direitos e cambotas horizontais de madeira, reforçado com cintas externas de ferro redondo, encaixadas em ranhuras existentes do lado de fora destas peças. O espaçamento das cambotas depende do comprimento das chapas de cimento-amianto.

Estas cintas são ajustadas por meio de parafusas especlais.

Internamente as cambotas apresentam recortes ondulados onde se adaptam as chapas de cimento-amianto que constituem as paredes do silo.

As chapas são remontadas de alguns centímetros e pregadas sôbre as pés-direitos.

o raio da circunferência interna, que marca a posição dos pés-direitos, deve ser tal que permita o melhor aproveitamento possivel da largura das chapas, bastando o remontamento, de uma chapa sôbre outra, de uma canelura apenas.

A razão de se usar em chapas onduladas para êste fim é que estas oferecem maior resistencia do que as lisas.

A cobertura é constitulda, também, de chapas do mesmo material.

As janelas de descarga sáo construidas da mesma forma que as anteriores.

A caixa de descarga estabelece a ligaçāo entre o silo e o estábulo.

Os pés-direitos săo ancoradas por melo de ferro em $U$ no bloco da fundação.

A firma Montana Lta. se encarrega da construção e montagem de silos deste material.

Silos subterrâneos - Circulares : Desenho n. ${ }^{\circ}$ 12. Os silos subterrâneas, de forma cilíndrica, são muito usados pelas 


\section{SILD METÁLILD \\ CAPACIDADE 140 ư ou 95 9 50 r.}

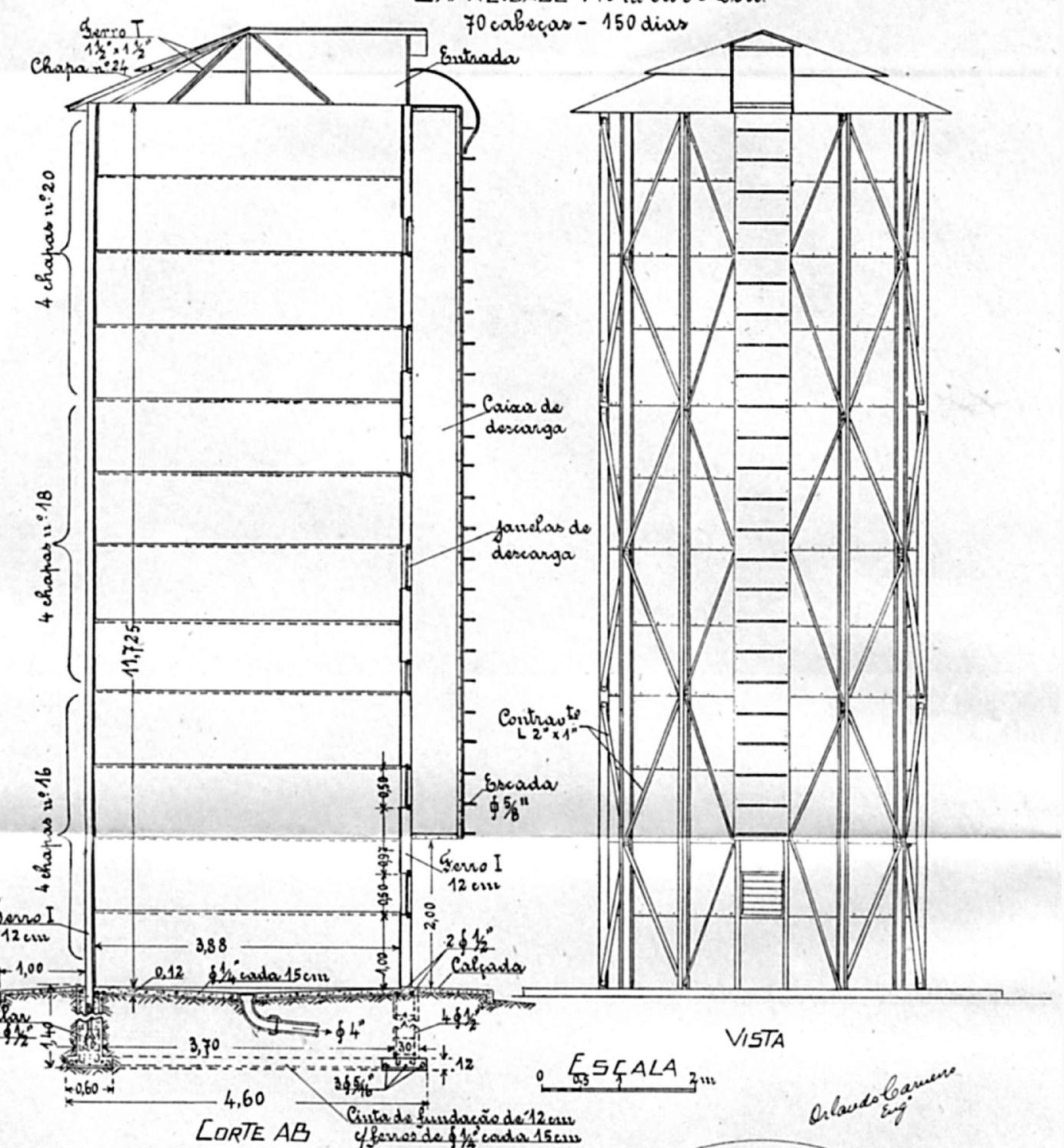

EenoTdo $12 \mathrm{~cm}$
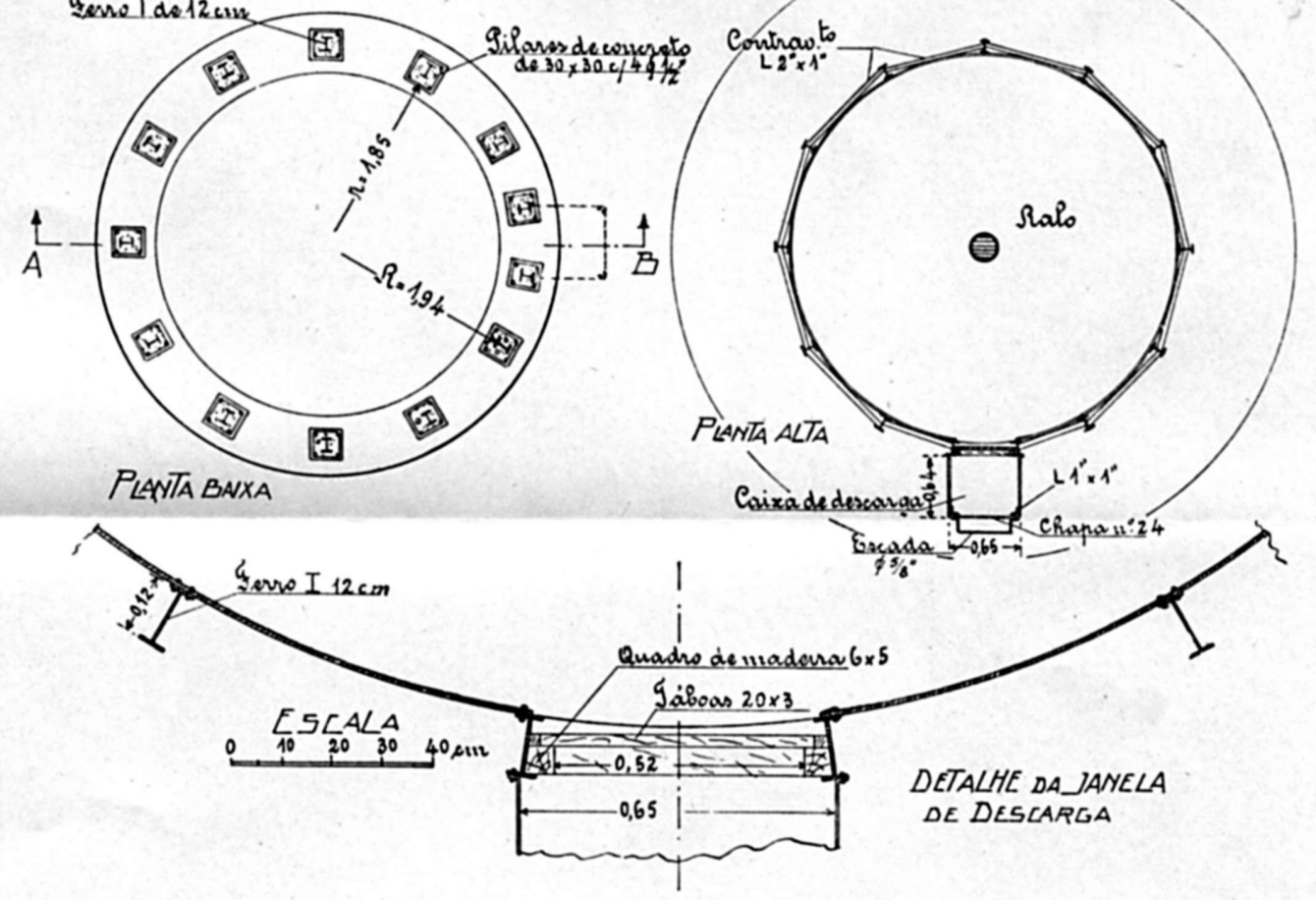

Desenho n. ${ }^{\circ} 10$ 
Estabula cam SIL ANeXo de

[IMENTI-AMIANTT
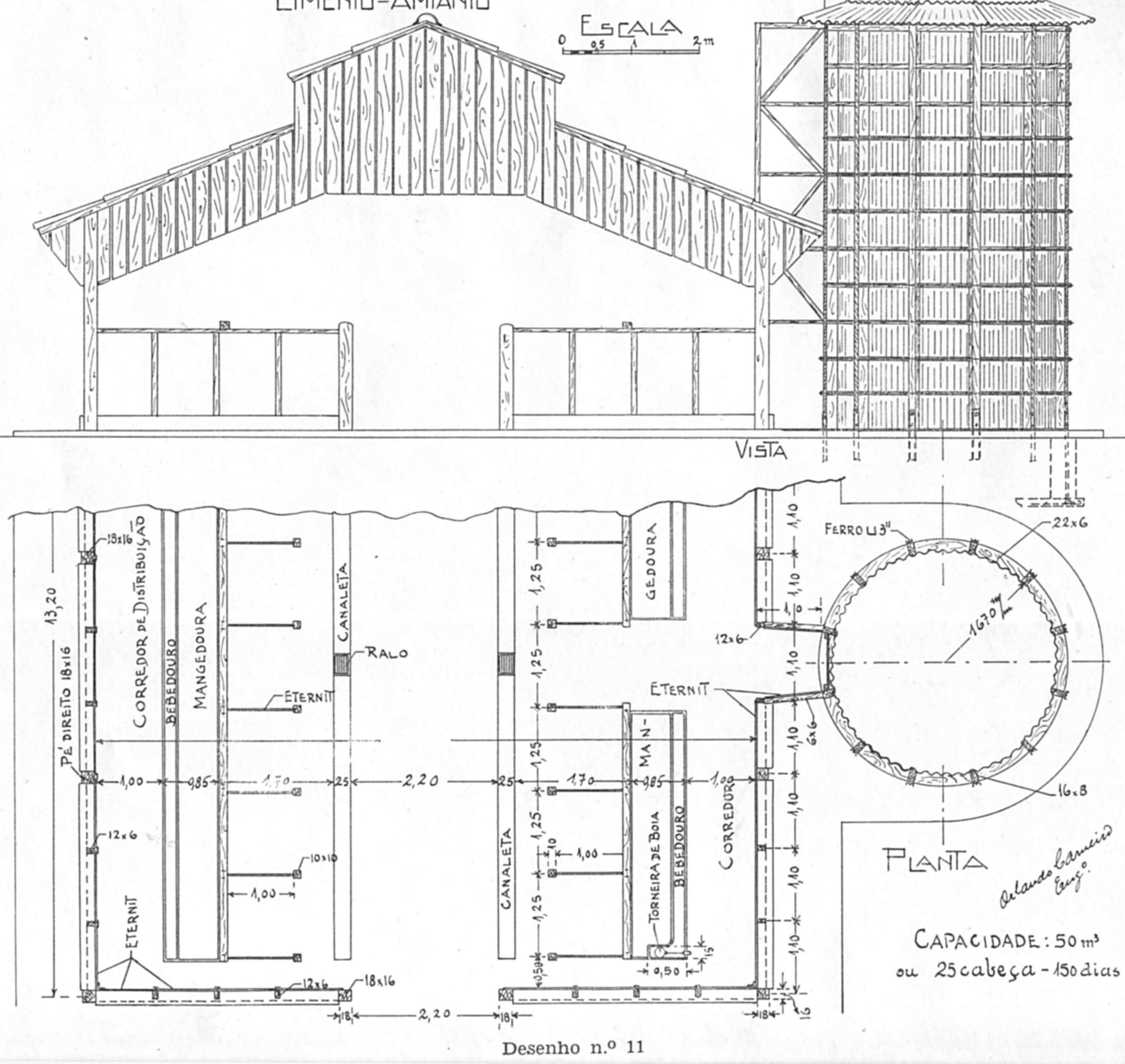

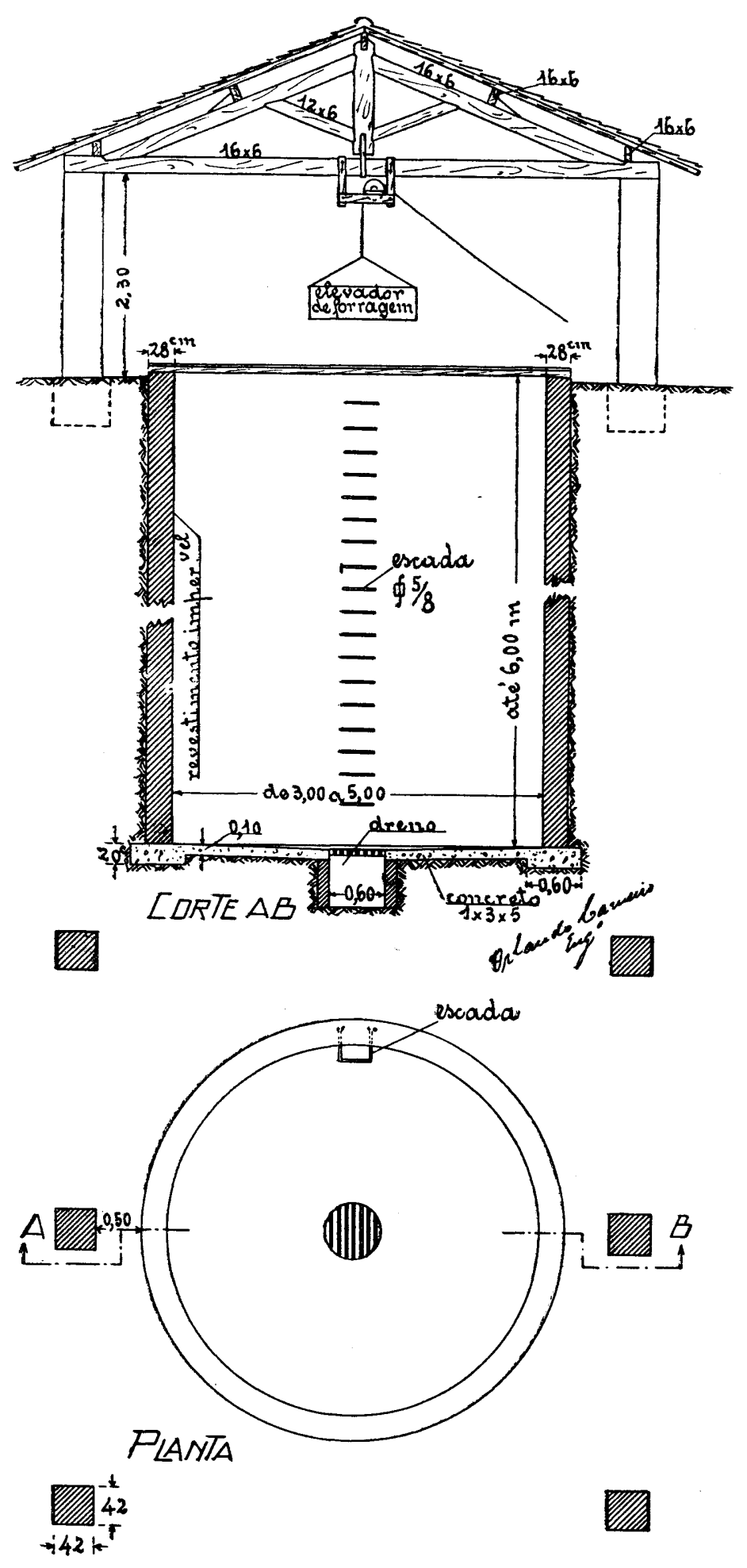

SILD SUBTERRÀMED LIRLULAR

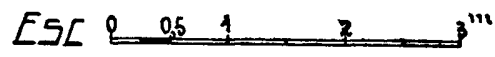

nocanhn no 19 
vantagens que apresentam de facilidade e economia de construção e comodidade de carregamento. A descarga é, porém, um pouco trabalhosa.

Devem ser construidos em terreno firme e sêco, podendo, neste caso, dispensar revestimento interno. Não se dispondo de local que satisfaça essas condiçōes, deve-se entāo revestir a cava com uma parede de 1 ou de $1 / 2$ tijolo, convenientemente impermeabilizada.

A profundidade dêstes silos não deve exceder de $6 \mathrm{~m}$, para não dificultar a remoção da forragem da parte inferior, serviço êste que se consegue mais facilmente com o auxilío de um elevador de cesta.

São em geral cobertos com um simples telheiro montado sôbre pés-direitos de madeira ou de tijolos, para evitar a entrada da água da chuva no interior do silo. Contudo é sempre conveniente se instalar, no fundo, um dreno.

$O$ diâmetro interno varia de 3,00 a $5,00 \mathrm{~m}$.

Silos subterrâneos - Em trincheira: Desenho n.o 13. Como os anteriores, devem ser construidos em terreno sêco e firme, podendo ser ou não revestidos.

Para evitar a entrada de água da chuva, pode-se protegê-los com uma coberta, que se remove por ocasião de descarga. Quando descobertos, depois de carregados, são protegidos com uma camada de capim, sôbre a qual se coloca outra de terra, apresentando, na parte superior, uma superfície abaulada.

O desenho n. ${ }^{\circ} 13$ representa, em secções transversais, alguns tipos de silos em trincheira, em terra e revestidos.

A água que por ventura entrar no silo, e o excesso de umidade serão absorvidos pelo terreno do fundo, que quando revestido deve ser munido de ralo.

Este tipo de silo, embora não seja construção de caráter duradouro, dá, contudo, bom resultado com dispêndio relativamente pequeno.

Silos de Encosta - Desenhos n. 14 e 15. Os silos de encosta são construidos no comêço das encostas dos morros ou em terreno de forte declive, tirando-se partido dessa disposição topográfica para tornar fácil o enchimento e a descarga.

Podem ser de alvenaria, semi-elevados como se indica no desenho n. ${ }^{\circ} 14$ ou subterrâneos, circulares e em trincheira.

O desenho n. ${ }^{15}$ mostra como proteger um silo de encosta, em trincheira, contra as águas da chuva, indicando também como dispor as galerias que facilitam a descarga. 
Medas-silos : Desenhas n. 16 e n. ${ }^{\circ}$ 17. As medas de capim, embora năo mereçam o nome de silo e; muito menos, de construçőes, servem, contudo, para armazenar durante algum tempo à forragem verde.

Săo apoiadas em armaçóes de madeira, de diversos modos. As figuras n..$^{\circ}$ e n..$^{\circ} 17$ indicam os dois modas mais usadas de se fazerem essas armaçóes.
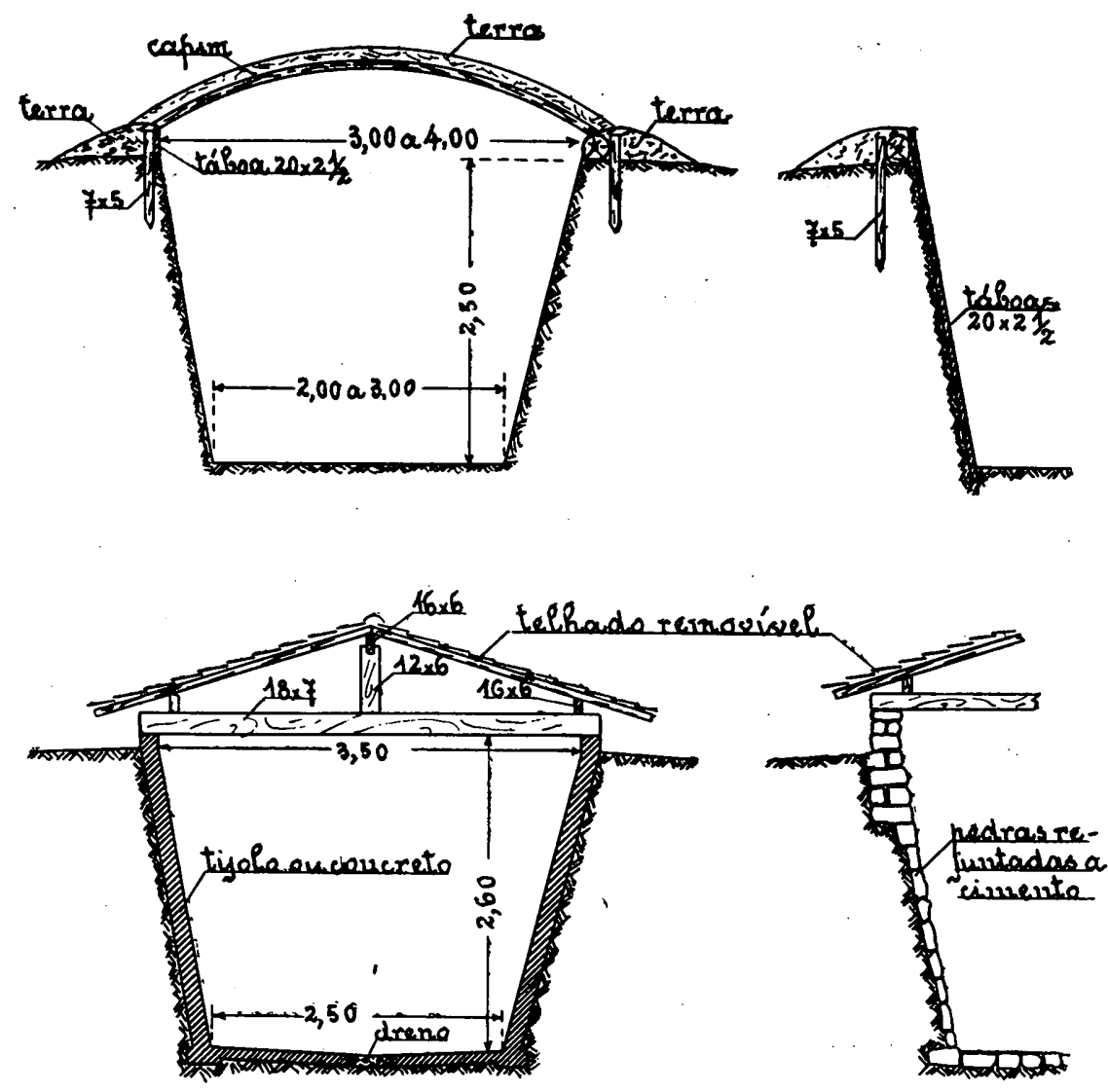

SECDES TRAMSVERSAIS DE SILDS TRIMLHEIRA

Desenho n.0 13 

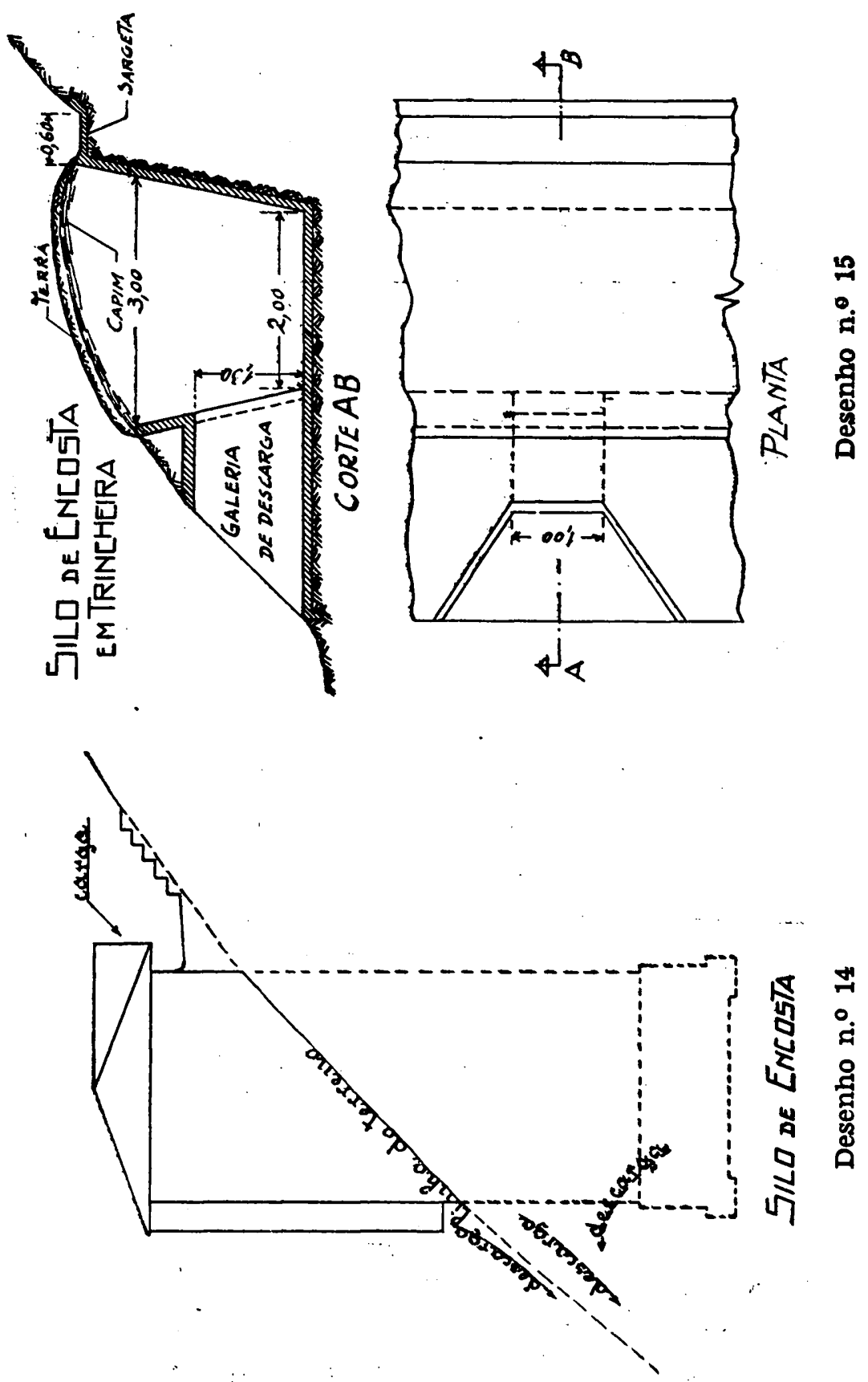

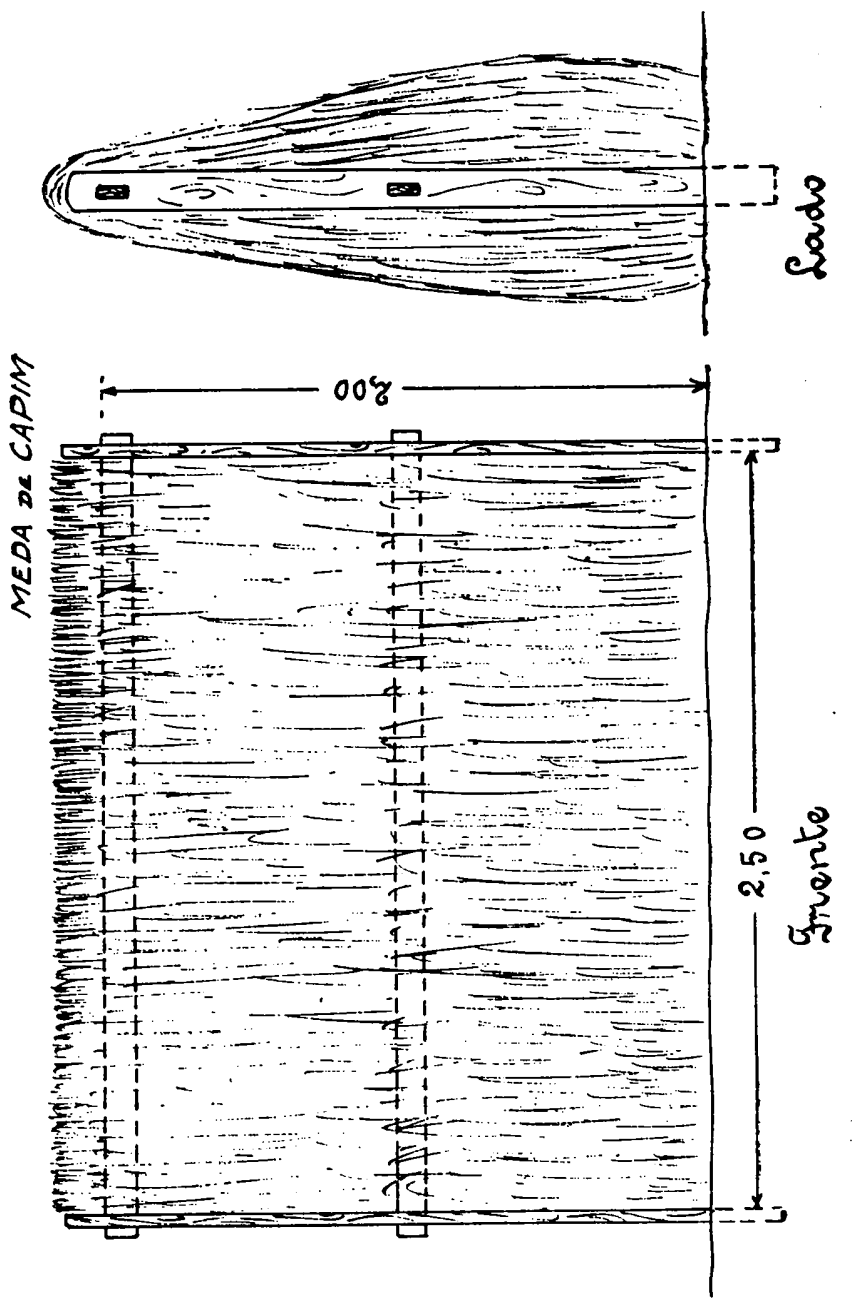

둘.

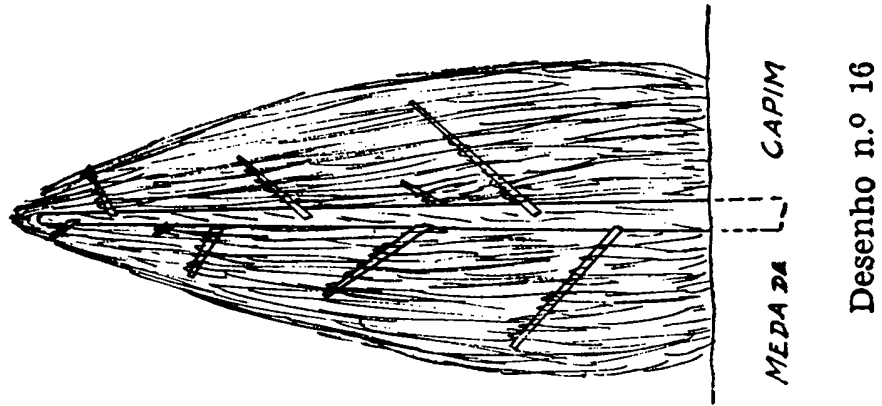




\section{CONSERVAÇAO - PRESERVAÇAOO}

Todos as silos devem ser lavados e até desinfetados internamente, antes de iniciada a carga.

Os metálicos sáo pintadas interna e externamente cada tres anos, mais ou menos.

Quando de madeira, esta convém ser previamente tratada com o fim de preservá-la contra o ataque de fungas e bactérias.

Hsse tratamento pode ser feito de diversos modos. Citaremos alguns; banho, imersão : ou pintura com : sulfato de cobre, solução de cal com arseniato de cálcio, bicloreto de mercúrio (sublimado corrosivo), fluoreto de sódio, cloreto de zinco, creasoto ou óleo creasotado, sais de Wolmann.

Resta saber se essas soluçס̄es não passam à forragem e se não serăo, portanto, prejudiciais ao gado.

\section{CARGA}

Quando a altura é pequena, até $4,00 \mathrm{~m}$, a carga se faz com o auxilio de escada, armaçбes de madeira, rampas, etc. Quando superior a $4,00 \mathrm{~m}$, convém usar elevadores apropriados, ventiladores, esteiras sem fim, canecas ou caçambas, etc., movidos a motores elétricos ou de explosáo. Os ventiladores podem ser combinados com as máquinas de picar forragem. Ver desenhos n. ${ }^{\circ} 18$ e n. ${ }^{\circ} 19$.

A forragem, ao cair no silo, é arrumada e acamada por um operário que a comprime com os pés, adensando-a convenientemente, tratando-se, é claro, de forragem verde.

No fim de algum tempo o volume diminui com o desprendimento de gazes. Completa-se, então, a carga do silo. A densidade vai aumentar consideravelmente.

Quando a carga é feita com ventiladores, começa-se pela janela de baixo, com o fim de se economizar energia.

\section{DESCARGA}

Nos silas elevados é feita pelas janelas e caixa de descarga.

Nas silas subterráneos circulares utiliza-se uma cesta ou calxa alçada por melo de corda e carretilha.

As janelas de descarga por onde se lança a forragem são aberturas de $60 \times 60 \mathrm{~cm}$, aproximadamente, e constam de um quadro de ferro em $\mathrm{L}$ ou $\mathrm{T}$ ou de madeira, de encontro ao qual 


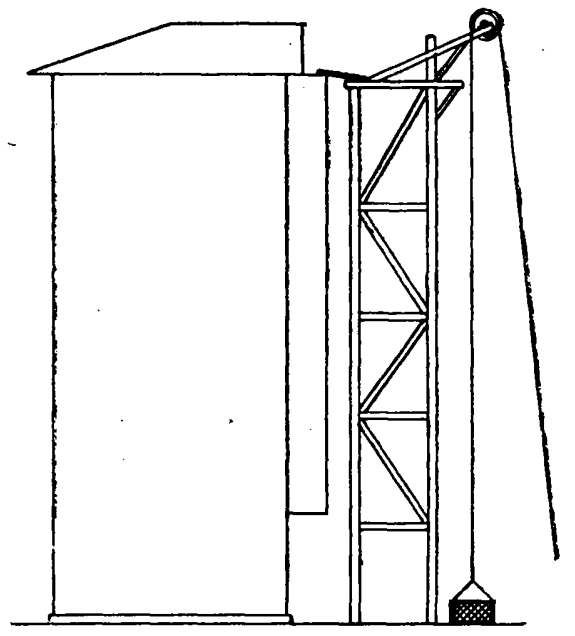

CARGA COM AUXILIODE ARMAGAÓ Desenho n.o 18

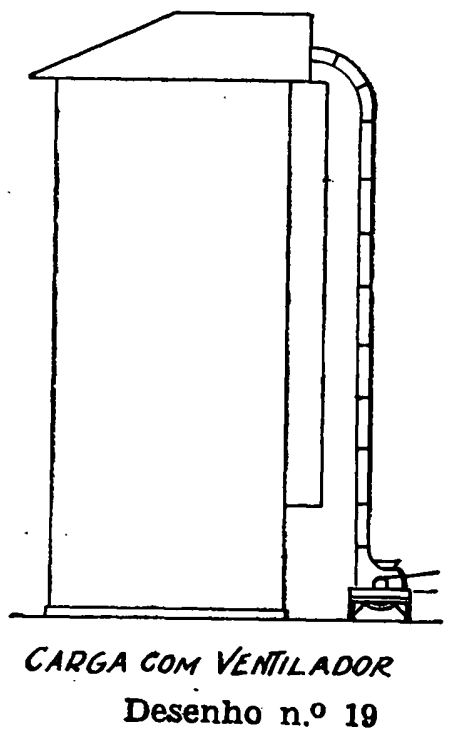


se adapta uma folha de chapa metalica ou de madeira, em uma só peça ou em segmentos.

Para evitar a entrada de ar e umidade as janelas săo munidas de juntas de borracha ou de papel alcatroado.

A calxa de descarga pode ser seml-circular ou de secçáo retangular, tendo, internamente, diametro de $0,70 \mathrm{~m}$ ou $60 \mathrm{x}$ $70 \mathrm{~cm}$ de lados. Serve para encaminhar a forragem, quando é lançada pelas janelas. Começa a 2,00m acima do solo e val até em cima. Pode ser metálica, de concreto armado, de madeira, ou de chapas de cimento-amianto, nestes dols ultimas casos pregadas sobre caibros.

Internamente deve oferecer superficie livre de saliencias, para nžo prender a forragem, quando se descarrega o silo, por isso, quando de madeira ou de cimento-amianto as táboas ou as chapas devem ser pregadas do lado de dentro da respectiva armaçăo.

\section{SILOS GRANDES OU PEQUENOS ?}

Quando é grande o número de cabeças, talvez seja preferivel construir mais de um sillo, em vez de um só de grande capacidade, pois isso pode facilitar a carga e descarga e apresentar vantagens para o corte e distribuiçáo da forragem.

Quando construidos em série, devem guardar espaços convenientes entre si, para facilitar a circulaçăo dos vefculas.

\section{LOCALIZAÇAO}

Devem ser construidas em terreno seco e firme e próximos das centros de consumo da forragem, podendo, mesmo, ser anexas aos estábulas, cavalariças, apriscos, etc. 
